\title{
The Proper Scope of the Police Power
}

Randy E. Barnett

Georgetown University Law Center, rb325@law.georgetown.edu

Vol. 79 Notre Dame Law Review, p. 429 (2004). Reprinted with permission. @ Notre Dame Law Review, University of Notre Dame.

This paper can be downloaded free of charge from:

https://scholarship.law.georgetown.edu/facpub/508

79 Notre Dame L. Rev. 429-495 (2004)

This open-access article is brought to you by the Georgetown Law Library. Posted with permission of the author. Follow this and additional works at: https://scholarship.law.georgetown.edu/facpub

Part of the Constitutional Law Commons, and the Legal History Commons 


\title{
ARTICLES
}

\section{THE PROPER SCOPE OF THE POLICE POWER}

\author{
Randy E. Barnett*
}

The conservation of private rights is attained by the imposition of a wholesome restraint upon their exercise, such a restraint as will prevent the infliction of injury upon others in the enjoyment of them .... The power of the government to impose this restraint is called Police Power. ${ }^{1}$

\section{INTRODUCTION}

When it comes to identifying the powers of the federal government, we know where to look. Article I of the Constitution provides a list. The debate is, and has always been, how to interpret the meaning of these provisions and how broadly or narrowly to construe that meaning. When it comes to the power of states over their people, the issue has always been shrouded in doubt. For, though the Constitution provides a list of specific limitations on state powers along with an enumeration of certain rights, it does not provide any written list of state powers or even a general statement as to their scope. In short the Constitution is, or at least to some appears to be, all but silent on the question of the proper scope of what is called the police power of states.

This apparent silence has invited a fundamental choice between two ways of construing the scope of state power. Some have con-

* Austin B. Fletcher Professor, Boston University School of Law. My thanks to Kate McFarland for her research assistance. This Article expands upon and revises material that will appear in RANDY E. BARNETT, RESTORING THE LOST CONSTITUTION: The Presumption of Liberty (forthcoming 2004). Permission to photocopy for classroom use is hereby granted.

1 Christopher G. Tiedeman, A Treatise on the Limitations of Police Power in the United States Considered from both a Civil and Criminal Standpoint 1-2 (St. Louis, F.H. Thomas Law Book Co. 1886). 
tended that the state, being a government of "general powers," may do all that is not expressly prohibited by the express provisions of the Constitution. Others contend that, because governments with unlimited power are a form of tyranny, some limits to the powers of states must be identified.

One response to this is that state governments are limited, but only by their own state constitutions. Of course, these are not the only limits on state powers. Everyone concedes that even powers authorized by state constitutions are limited by the express prohibitions on state powers in Article I as well as the restrictions imposed by the Bill of Rights. So the claim is that, except where limited by the federal Constitution, states' powers are limited only by their constitutions. This begs the question of whether any additional restrictions are imposed on the states by the Constitution and, as we shall see, there are-in the Fourteenth Amendment.

In this Article, I will contend that the Constitution is not really silent at all on the proper scope of state powers; that the original meaning of what the Constitution says requires that state powers over their citizens have fairly easy to identify limits-though as with most constitutional provisions, applying these limits to particular cases requires judgment and is not a matter of strict deductive logic. This account will require me to briefly review the method of interpretation I advocate-original meaning originalism-and its limits. These limits require that interpretation of original meaning be implemented by means of constitutional constructions that enhance the legitimacy of the Constitution without violating the original meaning established by interpretation. I then examine the original meaning of the provision that provides the limit on state power: the Fourteenth Amendment. Finally I offer the construction of the scope of the police power of states that is consistent with that limitation: the police power of states includes the power to prohibit wrongful and to regulate rightful conduct of individuals. ${ }^{2}$

Throughout this Article, it is wise to be aware of an irony lurking behind debates among legal scholars on the proper scope of the police power of states. These powers are unwritten and, as a result, lack all specificity associated with the rule of law. In response to this, some

2 I say "includes" because the police power may have other aspects as well, in particular, a more extensive power to regulate or rêstrict the use of state owned property. But this is an aspect of state power I will not be addressing here. I am concerned instead with the general power the state has over its citizens, wholly apart from the powers it may exercise as a property owner in its own right. Where these two issues overlap to some extent is the state's power to regulate behavior in public places, such as streets, sidewalks, and parks. 
argue that the powers are for most intents and purposes unlimited, meaning that state legislature have the power to enact what they will, free of any constitutional constraints imposed by the federal judiciary. In contrast, as I shall show, both the Ninth and Fourteenth Amendments provide an express recognition of unenumerated rights, privileges or immunities retained by the people, while the Tenth Amendment expressly states that the powers not delegated to the federal government are reserved to the states or to the people-without specifying which.

Confronted with this text, however, many of the very same scholars object that because the content of these rights are unwritten or unspecified, these textual provisions should generally be ignored and forgotten (as well they have been). The objection is that recognizing unwritten rights provides no rule-like constraints on the powers of judges to strike down legislation. But they are not similarly bothered by giving a blank check to legislatures in the form of an unlimited construction of their entirely unwritten police power. The irony of this approach is that unwritten powers become unlimited, in contrast to unenumerated rights expressly recognized by the Constitution, which are made to vanish.

\section{Constitutional InTERPRetation and Construction}

Every discussion of the meaning of the Constitution should begin with the writer identifying his or her method of interpretation. Even if that method cannot be defended completely in the particular context, an author should provide some indication of the reasons for the adoption of the particular chosen method. Too many discussions of the Constitution lack what should be this obligatory preface, leaving the reader unable fully to assess the particular interpretation being offered. ${ }^{3}$

I have argued elsewhere that a written constitution should be interpreted according to its original meaning; that we are not bound by the original intention of its framers, but only by the original meaning of the words they enacted (though evidence of intention may tell us something about what the words meant to a member of the general public at the time of enactment). The justification of this approach, in the United States, stems from two features of the Constitution: (1)

3 To be clear, my claim concerning the need to identify one's interpretive methodology is limited to writings that advocate a particular interpretation or oppose another. This need not be done if the treatment is for some other purpose, such as a purely historical discussion or an analysis of cases in which no interpretation of the Constitution itself is advocated. 
that one of its principal purposes is to constrain those who make and enforce laws so as to protect the rights retained by the people, and for this reason, (2) it is put in writing.

Because this is the law governing lawmaking, those who make the laws that are to govern the people should not be able to change the laws that govern them. Putting these laws over the lawmakers in writing serves to lock them in, and this "lock in" function would be defeated if those who make or enforce laws, or who interpret the writing, are free on their own to change it to something different that they prefer. In short, for a written constitution to perform the principal function for which it is put in the form of a writing, its meaning must remain the same until it is properly changed. And it is improper for it to be changed by the very people it is supposed to bind.

By this rationale, the original meaning of the text is to be preserved, but not because its authors have any authority over the living. It is to be preserved because the system of lawmaking we currently have has a structural feature-the written limitation of the power of lawmakers. The vital function of this feature would be destroyed, to the detriment of the rights retained by those alive today, if the meaning of the writing can be changed by those whom it is supposed to constrain. Originalism is justified, therefore, as an essential means of protecting the rights retained by the people.

While the original meaning of the text might be demonstrably inconsistent with a multitude of possible outcomes, however, it may still not provide enough guidance to identify a single rule of law to apply to a particular case at hand. Indeed, it frequently will not. When this occurs, it becomes necessary to adopt a "construction" of the text that is consistent with its original meaning but not deducible from it.

For example, as we shall see, the original meaning of the text calls for the protection of the natural liberty rights retained by the people along with any additional privileges or immunities created by the Constitution itself. In contrast, the text provides no explicit reference to the proper scope of state powers. It most assuredly does not say that the states have all powers not delegated to the federal government. Indeed, the Tenth Amendment is expressly noncommittal on the scope of state powers when it affirms that " $[\mathrm{t}]$ he powers not delegated to the United States by the Constitution, nor prohibited by it to the States, are reserved to the States respectively, or to the people."

Any claim concerning the proper scope of state power is, therefore, a construction, rather than an interpretation of the text. This is

4 U.S. Const. amend. X (emphasis added). 
not to disparage it, as constitutional construction is inevitable. It is only that a constitutional construction is not a product of interpretation based on original meaning, except indirectly, when the original meaning of what the text does say is consistent with one construction, and inconsistent with another.

This is the case with the police power. We shall see that the unlimited or plenary power construction of the police power is inconsistent with both the text and original meaning of the Ninth and Fourteenth Amendments. In contrast, the construction I shall offer, which is not original to me, is consistent with these express provisions.

In addition, when choosing among possible constructions of the text that are consistent with its original meaning, we should choose that construction which enhances the legitimacy of the Constitution, by which I mean its ability to create a lawmaking process that binds in conscience or to create a duty of obedience in the citizenry. I have defended this conception of constitutional legitimacy elsewhere. ${ }^{5}$ By violating the rights retained by the people, the unlimited or plenary power construction of the state police power undermines rather than enhances the ability of constitutional lawmaking processes to produce laws that bind the people in conscience. In contrast, the construction I will propose respects the rights retained by the people and enhances constitutional legitimacy in the relevant sense.

\section{Interpreting What the Constitution Says: The Original Meaning of the Ninth and Fourteenth Amendments}

Before the Civil War, unless a state law violated one of the expressed prohibitions in the Constitution, it could not be challenged in federal court. In 1833, the Supreme Court, in Barron $v$. Mayor of Baltimore, ${ }^{6}$ held that the Bill of Rights applied only to the federal government and did not constrain the states (notwithstanding that the text of some of the first ten amendments contains no such limitation). Thus, at the founding period and for decades thereafter, the propriety of state laws received minimal federal scrutiny. ${ }^{7}$

Upon passage of the Fourteenth Amendment, however, the constitutional structure changed. States were now prohibited from

5 See Randy E. Barnett, Constitutional Legitimacy, 103 Colum. L. Rev. 111 (2003).

632 U.S. (7 Pet.) 243 (1833).

7 Though, as will be noted below, state court judges began to scrutinize the propriety of state legislation under the "law of the land" provisions in state constitutions to ensure that such legislation served the general public, as opposed to a faction or special interest. See Howard Gillman, The Constitution Besieged: The Rise and Demise of Lochner Era Police Powers Jurisprudence 45-60 (1993). 
abridging any of the "privileges or immunities" of their citizens-a phrase that, as we will see, included the background natural rights of the people along with other rights and privileges of citizenship expressly created by the Constitution. In addition, states could not deprive persons of life, liberty, or property without due process of law or deny them the equal protection of the laws. Federal courts were now required to assess whether states had violated any of these prohibitions.

Owing to the Fourteenth Amendment, therefore, state governments no longer can claim a plenary power to restrict the liberties of the people subject only to their constitutions and any express restrictions in the original Constitution. Instead, any state abridgment of the privileges or immunities should be subject to challenge in federal court. When state legislatures restrict the liberties of the people, they are no more entitled to be the judge in their own case than is Congress. The exercise of liberty by the citizen should not be restricted unless the state can show, to the satisfaction of an independent tribunal of justice, that such a restriction is both necessary and proper.

Determining the propriety of state laws is more problematic than with federal powers, however, because there is no list of enumerated powers the original meaning of which can be used to distinguish proper from improper exercises of power. Indeed, there is nothing in the Constitution that speaks to the issue of the proper scope of state powers. While the Tenth Amendment establishes that federal powers are limited to those that are enumerated, it does not say whether any particular power is in the hands of the states or of the people. As Justice Thomas has correctly observed, " $[w]$ ith this careful last phrase, the Amendment avoids taking any position on the division of power between the state governments and the people of the States ...." 8 To answer that question we must look elsewhere.

Originally, the obvious places to look were state constitutions to see what powers a particular state had been granted. ${ }^{9}$ However, as was already mentioned, the enactment of the Fourteenth Amendment complicated this by forbidding states from improperly abridging the privileges or immunities of their own citizens even where permitted by their constitutions. In determining the proper scope of state power, then, it becomes necessary to establish the original meaning of this

8 U.S. Term Limits, Inc. v. Thornton, 514 U.S. 779, 848 (1995) (Thomas, J., dissenting).

9 See id. (Thomas, J., dissenting) ("It is up to the people of each State to determine which 'reserved' powers their state government may exercise."). 
restriction. A state may only exercise whatever degree of power is consistent with these express restrictions.

Because the evidence shows the Privileges or Immunities Clause was, in part, a reference to natural rights, its proper interpretation requires an appreciation of what is meant by natural rights. This in turn requires that we begin our investigation into that textual injunction in the original Constitution that protected unenumerated natural rights from federal power: the Ninth Amendment.

\section{A. The Original Meaning of the Ninth Amendment}

1. The Reason for the Ninth Amendment: The Equal Protection of Unenumerated Rights

The Ninth Amendment ${ }^{10}$ was the creation of James Madison. Both his reason for devising it and his use of the amendment in constitutional argument support the most obvious textual meaning: unenumerated liberties are to be treated the same as those that were enumerated. To the degree that enumerated rights receive protection from Congress, so too should those that were left unenumerated. To appreciate this, we need to begin by understanding the problem that the Ninth Amendment was enacted to solve.

Until the Bill of Rights was adopted two years after the ratification of the Constitution, with a few exceptions, all of the rights retained by the people were unenumerated. There was no explicit protection for the rights of free speech and assembly or the rights of freedom of religion and of the press. During this period no one argued that the federal government had the power to abridge or deny these and other unenumerated liberties. In the absence of explicit mention in the Constitution, how were these rights to be protected?

The most obvious way was by the political constraints of federalism and separation of powers, which required a convergence of opinions before laws could be enacted and enforced. Their protection also came from the fact that the powers of Congress were limited and enumerated. Even when Congress was ostensibly acting within its powers, however, the means it chose to employ might still be unnecessary or improper. Finally, the judiciary was to be the guardian of the Constitution when Congress exceeded its powers, including its lawmaking power under the Necessary and Proper Clause. ${ }^{11}$ Taken to-

10 U.S. Const. amend. IX ("The enumeration in the Constitution of certain rights shall not be construed to deny or disparage others retained by the people.").

11 See Randy E. Barnett, The Original Meaning of the Necessary and Proper Clause, 6 U. PA. J. Const. L. 183 (2003). 
gether, these structural and textual constraints prevented whole categories of rights violations without having to discuss the rights themselves and contributed importantly to the legitimacy of the original Constitution.

When the opponents of the Constitution objected to the absence of a bill of rights, the Federalists argued that this additional protection was unnecessary because the Congress was not given any power to violate the rights retained by the people. "Why, for instance," asked Hamilton, "should it be said that the liberty of the press shall not be restrained, when no power is given by which restrictions may be imposed?" 12 As I shall discuss at greater length below, the Federalists also argued that adding a bill of rights would be dangerous because the rights or liberties of the people were unenumerable and any rights that would be omitted would be rendered insecure.

Despite their arguments, the Federalists were forced to promise a bill of rights to obtain enough support for ratification. When James Madison sought to honor this commitment in the first Congress, he was faced with solving the difficulty that he and his Federalist allies had noted just two years earlier. As soon as any particular rights or liberties were explicitly enumerated, the status of those left out of the enumeration became unclear. Were only the enumerated rights to be protected and the unenumerated rights left unprotected? By "unprotected" I mean subject to being surrendered up to Congress to be abridged or denied at its sole discretion.

Here is how Madison stated the problem when he introduced his proposed amendments to the House:

It has been objected also against a bill of rights, that, by enumerating particular exceptions to the grant of power, it would disparage those rights which were not placed in that enumeration; and it might follow by implication, that those rights which were not singled out, were intended to be assigned into the hands of the General Government, and were consequently insecure. This is one of the most plausible arguments I have ever heard urged against the admission of a bill of rights into this system; but I conceive, that it may be guarded against. ${ }^{13}$

Madison then referred the members to the portion of his proposal that read:

The exceptions here or elsewhere in the Constitution, made in favor of particular rights, shall not be so construed as to diminish

12 The Federalist No. 84, at 513-14 (Alexander Hamilton) (Clinton Rossiter ed., 1961).

131 Annals of Cong. 439 (Joseph Gales ed., 1789). 
the just importance of other rights retained by the people, or as to enlarge the powers delegated by the constitution; but either as actual limitations of such powers, or as inserted merely for greater caution. ${ }^{14}$

Eventually, all of Madison's proposals were referred to a select committee of the House, which decided to list the amendments after the body of the original Constitution rather than insert them within the text. From this committee emerged the current text of the Ninth Amendment, which replaced the "diminish the just importance" language with the stronger phrase "deny or disparage." While there is much that is controversial about the Ninth Amendment, this story of its origin and enactment is not.

What do Madison's original proposal, and his explanation of it, add to our understanding of the Ninth Amendment? First of all, Madison's placement of this provision is revealing. He put it at the end of the list of specific individual rights that he proposed be inserted in Article 1, Section 9, immediately after the two individual rights already listed there - the rights of habeas corpus and the rights against bills of attainder and ex post facto laws-but before the other prohibitions of government power listed in Section 9 that are not easily conceived as individual rights, such as the prohibition on granting titles of nobility. This supports a conclusion that it refers to the same sorts of individual rights that were explicitly enumerated in the Constitution and that it was to be accorded the same importance as the other provisions in that section.

Then there are the words of the original proposal that were quoted above, which convey information about the nature of both enumerated and unenumerated rights omitted from the otherwise stronger final version. Owing to his tendency to run parallel ideas together in a single sentence, Madison's original proposal is a bit difficult to follow. When disentangled, however, it shows clearly that the rights enumerated in the Bill of Rights were of at least two kinds.

First were those enumerated rights that provided additional or "actual limitations" on the delegated powers beyond those that previously existed. For example, prior to its amendment, the Constitution did not require jury trials in civil cases. In his speech to the House, Madison categorized these actual limitations as "positive rights" and gave the example of trial by jury. ${ }^{15}$ Second were those rights that were

141 id. at 435.

$151 \mathrm{id}$. at 436 . For this item, Madison's notes read: "4. positive rights resultg. as trial by jury." Madison's Notes for Amendments Speech 1789, in 1 THE Rights Retained By the People: The History and Meaning of the Ninth Amendment 64 (Randy E. Bar- 
enumerated "merely for greater caution." As Madison explained, these refer to "those rights which are retained when particular powers are given up to be exercised by the Legislature." 16 Crucially, in his handwritten notes to this speech, Madison refers to these "rights which are retained" as "natural rights" and gives as an example of such a natural right the freedom of speech. ${ }^{17}$

Thus, according to how Madison used the term "retained" rights, we know that the "other" unenumerated rights "retained by the people" mentioned in the Ninth Amendment fall into the second category of his original proposal. They are the natural rights "which are retained when particular powers are given up to be exercised by the Legislature." 18 A few of these rights were included in the Bill of Rights "for greater caution" but most were left unenumerated. They were not left textually unprotected, however. The textual source of that protection was, initially, the limited powers scheme and the Necessary and Proper Clause, ${ }^{19}$ and soon thereafter the enumeration of certain rights coupled with the Ninth Amendment for the others.

Madison's speech to the House also clarifies how constitutional rights, whether enumerated or unenumerated, relate to the delegated powers. Constitutional rights can limit both the ends of government as well as the means by which the legitimate ends of government are executed. As Madison explained (in another sentence combining parallel ideas), "the great object in view is to limit and qualify the powers of Government, by excepting out of the grant of power those cases in which the Government ought not to act, or to act only in a particular mode." 20 Disentangling this passage, we find that ends constraints "limit . . . the powers of Government" by specifying when "the Government ought not to act." Means constraints " qualify the powers of Government" by specifying when "Government ought . . . to act only in a particular mode."

nett ed., 1989) [hereinafter Rights Retained]. The next type of rights mentioned both in his speech as delivered and in his notes are

positive rights, which may result from the nature of the compact. Trial by jury cannot be considered as a natural right, but a right resulting from a social compact which regulates the action of the community, but is as essential to secure the liberty of the people as any one of the pre-existent rights of nature.

1 Annals of Cong. 436 (Joseph Gales ed., 1789).

161 Annals of Cong. 437 (Joseph Gales ed., 1789).

17 Madison's notes read: "Contents of Bill of Rhts. . . 3. natural rights retained as speach.” Madison's Notes for Amendments Speech 1789, supra note 15, at 64.

181 Annals of Cong. 437 (Joseph Gales ed., 1789).

19 See generally Barnett, supra note 11.

201 Annals of Cong. 437 (Joseph Gales ed., 1789). 
As an example of improper means, Madison offered the use of general warrants: "The General Government has a right to pass all laws which shall be necessary to collect its revenue; the means for enforcing the collection are within the direction of the Legislature: may not general warrants be considered necessary for this purpose . . ?"21 As Madison's example suggests, the Necessary and Proper Clause exacerbates the means-end problem within a scheme of delegated powers. Authorizing the Congress " $[\mathrm{t}] \mathrm{o}$ make all Laws which shall be necessary and proper for carrying into Execution the foregoing Powers, and all other Powers vested by this Constitution in the Government of the United States, or in any Department or Officer thereof"22 heightens the prospect that Congress or some department or officer of the general government may pursue a delegated enumerated end by means that infringe upon the rights retained by the people. Therefore, some regulation of the means employed to achieve enumerated governmental ends must supplement the device of enumerating powers.

In his speech, Madison explicitly linked the abuse of the Necessary and Proper Clause with the need for constitutional rights to constrain the means chosen by the general government:

It is true, the powers of the General Government are circumscribed, they are directed to particular objects; but even if Government keeps within those limits, it has certain discretionary powers with respect to the means, which may admit of abuse to a certain extent, . . . because in the Constitution of the United States, there is a clause granting to Congress the power to make all laws which shall be necessary and proper for carrying into execution all the powers vested in the Government of the United States, or in any department or officer thereof . . . .23

As the Supreme Court stated in Dennis v. United States, ${ }^{24}$ " $[\mathrm{t}]$ he question with which we are concerned here is not whether Congress has such power, but whether the means which it has employed conflict with the First and Fifth Amendments to the Constitution."25

In addition to placing actual or additional limits on the means by which government can accomplish its legitimate ends, Madison identified a second power-constraining function of constitutional rights:

\section{$21 \quad 1$ id. at 438.}

22 U.S. Const. art. I, $\$ 8$, cl. 18.

231 AnNals of Cong 438 (Joseph Gales ed., 1789).

24341 U.S. 494 (1951).

25 Id. at 501 (emphasis added); see also Barenblatt v. United States, 360 U.S. 109, 112 (1959) ("Congress . . . must exercise its powers subject to the . . relevant limitations of the Bill of Rights."). 
constitutional rights provide a "redundant" or cautionary safeguard in the event that delegated powers of government are given an overly expansive interpretation. Constitutional rights can help hold government to its legitimate enumerated ends in two ways. Rights can prevent the adoption of an expansive interpretation of enumerated powers in the first instance. Failing this, once a power has been expansively interpreted, the direct judicial protection of enumerated and unenumerated rights holds government within some limits.

Madison himself used the Ninth Amendment to check an expansive construction of delegated powers during the debate over the constitutionality of the national bank. Near the end of his speech in which he argued that the powers to incorporate a bank and grant it a monopoly were beyond those granted to Congress under the Necessary and Proper Clause, he observed: "The latitude of interpretation required by the bill is condemned by the rule furnished by the Constitution itself." 26 As one authority for this "rule" of interpretation, Madison cited the Ninth Amendment:

The explanatory amendments proposed by Congress themselves, at least, would be good authority with them; all these renunciations of power proceeded on a rule of construction, excluding the latitude now contended for. . . . He read several of the articles proposed, remarking particularly on the 11 th [the Ninth Amendment] and 12 th [the Tenth Amendment]; the former, as guarding against a latitude of interpretation; the latter, as excluding every source of power not within the Constitution itself. ${ }^{27}$

Thus, Madison viewed the Ninth and Tenth Amendments as playing distinct roles. Madison viewed the Tenth Amendment as authority for the rule that Congress could exercise only a delegated power. For example, Congress could not establish a post office or raise and support armies without a delegation of power to pursue these ends. ${ }^{28}$ In

262 Annals of Cong. 1899 (1791) (emphasis added).

$272 \mathrm{id}$. at 1901 (emphasis added). The numbering of the amendments changed because the first two amendments proposed by Congress were not ratified by the states. So what came to be called the First Amendment was originally the third amendment on the list submitted to the states. At the time Madison spoke, however, this outcome was not yet known. One of these two moribund proposals-which regulated congressional pay increases-became the Twenty-Seventh Amendment in 1992 when it was finally ratified by a sufficient number of states.

28 The Tenth Amendment is redundant of the list of enumerated powers coupled with the first sentence of Article I, which begins: "All legislative Powers herein granted shall be vested in a Congress of the United States . ..." U.S. Const. art. I, $\$ 1$ (emphasis added). For this reason, whereas Madison highlighted the importance of the Ninth Amendment in his Bill of Rights speech, he viewed the Tenth Amendment as largely superfluous: "Perhaps other. words may define this more precisely than the 
contrast, Madison viewed the Ninth Amendment as providing authority for a rule against the loose construction of these powers-especially the Necessary and Proper Clause-when legislation affected the rights retained by the people. As Madison concluded in his bank speech: "In fine, if the power were in the Constitution, the immediate exercise of it cannot be essential; if not there, the exercise of it involves the guilt of usurpation . . . ."29

Three years later, in 1794, Madison would again argue in Congress that the unenumerated rights retained by the people directly constrained congressional power. When Congress sought to censure the activities of certain self-created societies for their participation in the Whiskey Rebellion earlier that year, Madison contended that " $[w]$ hen the people have formed a Constitution, they retain those rights which they have not expressly delegated." 30 Here Madison was asserting that the unenumerated retained right to hold opinions constrained the power of Congress to issue a censure, in the same manner as "the liberty of speech, and of the press." ${ }^{11}$ Indeed, "the censorial power is in the people over the Government, and not in the Government over the people." 32 Strong words on behalf of supporters of insurrection.

Madison's uses of the Ninth Amendment show that, like the natural rights that were enumerated, the unenumerated rights retained by the people provide a twofold check on government power. Their existence argues against a latitudinarian interpretation of enumerated powers when those powers are used to restrict the liberties of the people; and the direct protection of the liberties of the people also effectively limits both the ends of government and the means by which these ends can legitimately be pursued. This from the man who devised the Ninth Amendment.

In his treatise on the Constitution, St. George Tucker, the editor of the American edition of Blackstone's Commentaries and one of the leading jurists and constitutional scholars of the founding era, offered a similar interpretation of the Ninth Amendment (while it was still referred to as the Eleventh Amendment). He began his explanation of the Ninth and Tenth Amendments by connecting them with the enumeration of powers and the Necessary and Proper Clause. He

whole of the instrument now does. I admit they may be deemed unnecessary; but there can be no harm in making such a declaration ...." 1 AnNals of Cong. 441 (Joseph Gales ed., 1789).

292 Annals of Cong. 1902 (1791) (emphasis added).

304 id. at 934 (1794).

314 id.

324 id. 
noted that "[a]ll the powers of the federal government," were "either expressly enumerated, or necessary and proper to the execution of some enumerated power." 33 He then described, as "one of the rules of construction which sound reason has adopted" the principle "that, as exception strengthens the force of a law in cases not excepted, so enumeration weakens it, in cases not enumerated." 34 This meant that, because the powers of government are enumerated, the inference from the text is that government is to have no powers beyond those expressly provided.

Tucker then offered a rule of construction that follows from this inference:

[I]t follows, as a regular consequence, that every power which concerns the right of the citizen, must be construed strictly, where it may operate to infringe or impair his liberty; and liberally, and for his benefit, where it may operate to his security and happiness, the avowed object of the constitution .... .35

Tucker shared with Madison the view that the Ninth Amendment provided an argument against a latitudinarian interpretation of the delegated powers, but he also made even clearer that the end of constitutional construction is the protection of individual liberty: both a "strict construction" of powers and "liberal construction" of rights. Tucker was proposing something very much like what I call a "Presumption of Liberty." 36

\section{The Rights "Retained by the People" Are Natural Liberty Rights}

So the rights retained by the people are to be treated on a par with those that are enumerated. What exactly are these unenumerated rights? I have already referred to them as "natural rights." The founding generation universally believed that laws should not violate the inherent or "natural" rights of those to whom they are directed. This is not to say that universal agreement existed about the precise content of these rights, though I believe there was considerable consensus about such rights in the abstract. Nor did everyone agree about the remedy that was appropriate for their violation. Still, the basic

33 St. George Tucker, Of the Constitution of the United States, in 1 Blackstone's Commentaries: With Notes of Reference to the Constitution and the Laws of the Federal Government of the United States and of the Commonwealth of VIRGinia app. at 307-08 (St. George Tucker ed., Philadelphia, William Young Birch \& Abraham Small 1803).

34 Id. at 308.

$35 I d$. at 307 (emphasis added).

36 See BARNeTt, supra note * (manuscript at 253-69, on file with author). 
concept of natural rights was clear: Natural or inherent rights are the rights persons have independent of those they are granted by government and by which the justice or propriety of governmental commands are to be judged. That the founding generation's commitment to natural rights is expressed in the Ninth Amendment's reference to "rights retained by the people" is overwhelming.

Let us begin with James Madison's speech to the House introducing his proposed amendments, including the provision that eventually became the Ninth Amendment. When explaining to the House the nature of the various rights contained in the amendments he was proposing, Madison stated that "[i]n [some] instances, they specify those rights which are retained when particular powers are given up to be exercised by the Legislature." ${ }^{37}$ Madison's notes for this part of his speech read: "[c] ontents of Bill of Rhts. . . 3. natural rights retained as speach." ${ }_{8}$ In other words, for Madison even some of the rights enumerated in the Bill of Rights, such as the freedom of speech, were natural "retained" rights.

Additional evidence that the term "retained" rights referred to natural rights can be found in the deliberations of the select committee that the House of Representatives appointed to draft amendments to the Constitution and on which Madison served. A draft bill of rights authored by fellow select committee member Representative Roger Sherman was found in the 1980s among Madison's papers. Sherman's second amendment read as follows:

The people have certain natural rights which are retained by them when they enter into Society, Such are the rights of Conscience in matters of religion; of acquiring property, and of pursuing happiness \& Safety; of Speaking, writing and publishing their Sentiments with decency and freedom; of peaceably assembling to consult their common good, and of applying to Government by petition or remonstrance for redress of grievances. Of these rights therefore they Shall not be deprived by the Government of the united States. ${ }^{39}$

Along the same lines, Madison proposed to Congress that the following be added as a prefix to the Constitution, " $[\mathrm{t}]$ hat Government is instituted and ought to be exercised for the benefit of the people; which consists in the enjoyment of life and liberty, with the right of

371 AnNals of Cong. 437 (Joseph Gales ed., 1789) (emphasis added).

38 See Madison's Notes for Amendments Speech 1789, supra note 15, at 64.

39 Roger Sherman's Draft of the Bill of Rights, in 1 Rights Retained, supra note 15, at 351 (emphasis added). 
acquiring and using property, and generally of pursuing and obtaining happiness and safety." 40

Indeed, the evidence both that the founding generation was committed to natural rights, and that this commitment is reflected in the words of the Ninth Amendment, is so overwhelming that few deny it. Instead, the argument is sometimes made that the only natural rights that may be protected by courts are those that were specifically enumerated in the Constitution. For the moment, however, I wish to examine why the Framers did not include a complete list of natural rights in the Constitution. The simple reason is that they thought it would be impossible to do so. Understanding why will help to illuminate the nature of the rights "retained by the people."

When opponents to the proposed constitution objected that it lacked a bill of rights, defenders argued vociferously that any effort to enumerate rights would be dangerous because the rights of the people were literally boundless. James Wilson, a member of the Constitutional Convention and the first professor of law at the University of Pennsylvania, was an ardent adherent of natural rights. In his lectures on jurisprudence delivered between 1790 and 1792, he explicitly rejected the views of both Edmund Burke and William Blackstone and contended instead that " $[\mathrm{g}]$ overnment, in my humble opinion, should be formed to secure and to enlarge the exercise of the natural rights of its members; and every government, which has not this in view, as its principal object, is not a government of the legitimate kind." 41 Nor for Wilson were these mere "theoretical" or "philosophical" rights with no real bite:

I go farther; and now proceed to show, that in peculiar instances, in which those rights can receive neither protection nor reparation from civil government, they are, notwithstanding its institution, entitled still to that defence, and to those methods of recovery, which are justified and demanded in a state of nature. The defence of one's self, justly called the primary law of nature, is not, nor can it be abrogated by any regulation of municipal law. ${ }^{42}$

Nevertheless, when defending the Constitution against those who complained about the absence of a bill of rights, Wilson explained,

401 Annals of Cong. 433-34 (Joseph Gales ed., 1789).

41 James Wilson, Of the Natural Rights of Individuals, in 2 The Works of James Wilson 296, 307 (James DeWitt Andrews ed., Chicago, Callaghan \& Co. 1896).

$42 I d$. at 335 (citations omitted). Wilson's lectures also undermine the claim that by the time of the Constitution, Americans had lost their Lockean and revolutionary ardor for natural rights in favor of a more conservative Blackstonian positivism that favored legislative supremacy. 
"there are very few who understand the whole of these rights." 43 None of the classical natural rights theorists, he said, claim to provide "a complete enumeration of rights appertaining to the people as men and as citizens. . . Enumerate all the rights of men! I am sure, sir, that no gentleman in the late Convention would have attempted such a thing." 44 And before the Pennsylvania ratification convention, Wilson observed:

In all societies, there are many powers and rights, which cannot be particularly enumerated. A bill of rights annexed to a constitution is an enumeration of the powers reserved. If we attempt an enumeration, everything that is not enumerated is presumed to be given. The consequence is, that an imperfect enumeration would throw all implied power into the scale of the government; and the rights of the people would be rendered incomplete. ${ }^{45}$

The same argument was made by Charles Pinckney in the South Carolina House of Representatives:

[W]e had no bill of rights inserted in our Constitution: for, as we might perhaps have omitted the enumeration of some of our rights, it might hereafter be said we had delegated to the general government a power to take away such of our rights as we had not enumerated ....46

Future Supreme Court Justice James Iredell stated a similar argument to the North Carolina ratification convention: "Let any one make what collection or enumeration of rights he pleases, I will immediately mention twenty or thirty more rights not contained in it." 47

To today's ears, this statement is startling. No matter how long a list of rights anyone might write, Iredell claimed he could add twenty or thirty more. What conception of rights could possibly lead someone of Iredell's stature to make such a claim in so visible a forum? What conception of rights would lead a natural rights theorist like Wilson to dèny that anyone in the Constitutional Convention would have presumed to enumerate all the rights retained by the people? And how could people with so expansive a view of rights, and who

432 The Debates in the Several State Conventions on the Adoption of the Federal Constrtution (Jonathan Elliot ed., Philadelphia, J.B. Lippincott 1836) 454 [hereinafter Elliot's Debates].

$442 i d$.

452 The Documentary History of the Ratification of the Constitution 388 (Merril Jensen ed., 1976).

464 Elliot's Debates, supra note 43, at 316.

$474 i d$. at 167 (quoting James Iredell at the North Carolina ratification convention, July 29, 1788). 
viewed them as so vitally important, have eventually adopted so short a list as those contained in the Constitution and the Bill of Rights?

One clue is to be found in the examples of natural "retained" rights provided by Roger Sherman in his proposed second amendment: "rights of Conscience in matters of religion; of acquiring property, and of pursuing happiness \& Safety; of Speaking, writing and publishing their Sentiments with decency and freedom; of peaceably assembling to consult their common good, and of applying to Government by petition or remonstrance for redress of grievances." Each of the rights on Sherman's list-which was not intended to be exhaustive ("such are") - are liberties or freedoms to believe or act in certain ways. They are not positive claims on government or on others.

The claim that natural rights are unenumerable and dangerous to enumerate makes complete sense if the term "inherent rights" or "natural rights" is used as a kind of synonym for "liberties" or Liberty (as distinct from license). That the term "natural rights" was synonymous with "liberties" is also exemplified in the official letter to Congress by the members of the Constitutional Convention who wrote that "[i] ndividuals entering into society must give up a share of liberty to preserve the rest .... It is at all times difficult to draw with precision the line between those rights which must be surrendered, and those which may be reserved . . .."48 Other direct evidence of the interchangeability of (natural) rights and liberties could be produced. ${ }^{49}$

According to this conception, natural rights define a private domain within which persons may do as they please, provided their conduct does not encroach upon the rightful domain of others. As long as their actions remain within this rightful domain, other personsincluding persons calling themselves government officials-should not interfere without a compelling justification. Because people have a right to do whatever they please within the boundaries defined by natural rights, this means that the rights retained by the people are limited only by their imagination and could never be completely specified or enumerated.

48 James Madison, Notes of Debates in the Federal Convention of 1787, at 627 (W.W. Norton \& Co. 1987) (1840) (emphasis added). I shall return to this quotation and its reference to "surrendered" rights in the next section of this Article.

49 See, e.g., 2 Elliot's Debates, supra note 43, at 201-02 (citing speech of Oliver Wolcott to the Connecticut ratifying convention, Jan. 18, 1788, discussing whether the proposed constitution "secures the liberties of the people, or whether its tendency be unfavorable to the rights of a free people"). $2 \mathrm{id}$. at 311 ("What is government itself but a restraint upon the natural rights of the people? What constitution was ever devised that did not operate as a restraint on their original liberties?") (emphasis added). 
This conception of rights as open-ended liberties is illustrated by an exchange that occurred during the debate in the House of Representatives over the wording of what eventually became part of the First Amendment. At one juncture in the debate, Representative Theodore Sedgwick criticized the select committee's inclusion of the right of assembly on the grounds that "it is a self-evident, unalienable right which the people possess; it is certainly a thing that never would be called in question; it is derogatory to the dignity of the House to descend to such minutia . . . ."50 Representative Egbert Benson replied to Sedgwick that " $[t]$ he committee who framed this report proceeded on the principle that these rights belonged to the people; they conceived them to be inherent; and all they meant to provide against was their being infringed by the Government." 51

Sedgwick's response to Benson is revealing of the conception of rights held generally at the time:

[I]f the committee were governed by that general principle, they might have gone into a very lengthy enumeration of rights; they might have declared that a man should have a right to wear his hat if he pleased; that he might get up when he pleased, and go to bed when he thought proper..${ }^{52}$

Notice that Sedgwick was not denying that one did indeed have a natural right to wear one's hat or go to bed when one pleased. To the contrary, he equated these "inherent" rights with the right of assembly, which he characterized as "self-evident" and "unalienable."53

Indeed, Representative John Page's reply to Sedgwick both made this equation of liberty rights explicit and showed that there was no disagreement that "inherent" or natural rights was a reference to an open-ended liberty.

[L] et me observe to him that such rights have been opposed, and a man has been obliged to pull off his hat when he appeared before the face of authority; people have also been prevented from assembling together on their lawful occasions, therefore it is well to guard against such stretches of authority, by inserting the privilege in the declaration of rights. ${ }^{54}$

Note too the use of the term "privilege."

501 AnNals of Cong. 731 (Joseph Gales ed., 1789).

511 id. at 731-32.

521 id. at 732.

531 id. at 731.

$541 \mathrm{id}$. (statement of John Page). 
Sedgwick's point was that the Constitution should not be cluttered with a potentially endless list of trifling rights ${ }^{55}$ that "would never be called in[to] question" 56 and were not "intended to be infringed." 57 Sedgwick's argument implicitly assumes that the "self-evident, unalienable," and inherent liberty rights retained by the people are unnumerable because the human imagination is limitless. All the actions one might take with what is rightfully his or hers can never be specified or reduced to a list. It includes the right to wear a hat, to get up when one pleases and go to bed when one thinks proper, to scratch one's nose when it itches (and even when it doesn't), to eat steak when one has a taste for it, or take a sip of Diet Mountain Dew when one is thirsty. Make any list of liberty rights you care to and one can always add twenty or thirty more.

The problem, therefore, with any explicit protection of these liberties is that the liberty of the people can never be completely enumerated or listed. An enumeration of rights is likely to be taken as evidence that the people surrendered up to the general government any liberty that is not on the list. With the inevitable danger created by any limited enumeration of unlimited rights specifically in mind, James Madison devised what became the Ninth Amendment.

That Madison and Sherman spoke of "retained" rights and that this word is used in the Constitution also supports the view that natural rights are liberty rights. For these are rights that people possess before they form a government and therefore retain; they are not the "positive" rights created by government. To be clear, I am not claiming that all constitutional rights are liberty rights. On the contrary, there are unquestionably positive rights created by the Constitution, and by other laws, and enforceable duties to respect these rights that government owes its citizens. I am claiming only that the natural "rights ... retained by the people" to which the Ninth Amendment refers are liberty rights.

\section{B. Did the People "Surrender" Their Natural Liberty Rights?}

Because the evidence of the founding generation's widespread commitment to natural rights is undeniable, some point to statements saying that people give up some of their natural rights when they enter into society and form a government. They also point to laws that restricted freedom as evidence that natural rights were not thought to

55 For a discussion of the founding generation's view of "trivial" rights, see Philip A. Hamburger, Trivial Rights, 70 Notre Dame L. Rev. 1 (1994).

561 Annals of Cong. 731 (Joseph Gales ed., 1789).

571 id. at 732. 
impose any legal or enforceable constraints on government. Sometimes it is claimed that the professed commitment to natural rights was rhetoric to justify a revolution, but when it came to governance, this rhetoric was muted or abandoned entirely.

There is no question that the Founders sometimes spoke of surrendering one's natural rights. They also enacted laws that some, then and now, might think violated natural rights. If, however, we approach these statements and practices with the same sympathy for natural rights that was felt by the founding generation we may find that they are reconcilable with a strong commitment to the liberty rights retained by the people. This account of natural rights will also be crucial to understanding how the Fourteenth Amendment could protect the liberty rights of citizens without giving the federal government complete control over matters ordinarily regulated by state law.

Let us begin with statements saying that one gives up one's natural rights when one enters into society or when one forms a government. Such statements were surely common. "What is government itself but a restraint upon the natural rights of the people?" 58 rhetorically asked a member of the New York ratification convention. "What constitution was ever devised that did not operate as a restraint on their original liberties?" 59 Robert Barnwell asserted to the South Carolina ratification convention that "in the compacts which unite men into society, it always is necessary to give up a part of our natural rights to secure the remainder. . .." 60

Sometimes these statements may even mean what they appear to say. Then, as now, there is not complete unanimity on any issue if we move beyond abstractions and generalities. But for every statement to this effect there are many more that refer to the natural rights still possessed by the people. This is significant because, when these statements were made, popular governments existed and citizens were not thought to be in a state of nature. ${ }^{61}$

582 Elliot's Debates, supra note 43, at 311 . Notice, too, that this statement also equates "natural rights" with liberty.

592 id.

$604 i d$. at 295 (statement of Robert Barnwell at the South Carolina convention, Jan. 17, 1788).

61 For the founding generation, the "state of nature" described the relationship between two or more persons who lack an established, common legal authority. See John Locke, Two Treatises of Government 326 (Peter Laslett ed., Cambridge Univ. Press 1988) (1690) ("[W] here-ever any two Men are, who have no standing Rule, and common Judge to Appeal to on Earth for the determination of Controversies of Right betwixt them, there they are still in the state of Nature, and under all the inconveniences of it."). Therefore, because they were subject to no common law and subject to no common magistrate, princes or heads of state might still be considered in a state 
Typical is the statement by the ratification convention of Virginia that formally accompanied its ratification of the Constitution-a statement also copied and adopted by the ratification conventions of North Carolina and Rhode Island: "That there are certain natural rights, of which men, when they form a social compact, cannot deprive or divest their posterity; among which are the enjoyment of life and liberty, with the means of acquiring, possessing, and protecting property, and pursuing and obtaining happiness and safety."62 To make sense of natural rights we should not use the aforementioned sorts of statements to discredit statements like these. Rather, we should appeal to a conception of natural rights that reconciles them both; and there is more than one way to reconcile them.

\section{Surrendering Only a Portion of Our Natural Rights}

First, most references to giving up one's natural rights when entering into society say, as does Barnwell's, that one surrenders only "a part of our natural rights" 63 while retaining others. Only those rights whose alienation is necessary to form a government are yielded. Typical of this idea is the official letter to Congress by the members of the Constitutional Convention (which I cited earlier to illustrate how the word "rights" was synonymous with the word "liberty"):64

It is obviously impracticable in the foederal [sic] government of these States to secure all rights of independent sovereignty to each, and yet provide for the interest and safety of all-Individuals entering into society must give up a share of liberty to preserve the rest. The magnitude of the sacrifice must depend as well on situation and circumstance, as on the object to be obtained. It is at all times difficult to draw with precision the line between those rights which must be surrendered, and those which may be reserved . . . ${ }^{65}$

What supposedly follows from statements about surrendering natural rights is that, despite the fact they are devised to constrain governments, natural rights no longer appear to operate as an effective

of nature with respect to each other. Furthermore, Locke contended that absolute monarchs "however intitled, Czar, or Crand Signior, or how you please, is as much in the state of Nature, with all under his Dominion, as he is with the rest of mankind." Id.

623 Elliot's Debates, supra note 43, at 657 (recounting George Wythe's June 27,1788 oral report listing the amendments to be considered for the proposed constitution). Notice how the draft bill of rights by Roger Sherman mirrors this statement except for the use by Sherman of the word "retained," which links this sort of statement to the rights "retained by the people" in the Ninth Amendment.

$634 \mathrm{id}$. at 295 (emphasis added).

64 See supra note 48 and accompanying text.

65 Madison, supra note 48, at 627 (emphasis added). 
constraint on government. This conclusion is unwarranted. At the time of the Founding, almost no one claimed or believed that one surrenders all one's natural rights up to government, but only those that were necessary. One cannot infer, then, from the fact that some natural rights were surrendered up, that other rights still retained by the people can be denied or disparaged with impunity.

Rather, the rights that are retained remain the measure of whether government is acting properly or improperly in the exercise of its delegated powers. As Madison explained to the Constitutional Convention, though the national government was formed to accomplish a variety of objects or ends, first among them was "the necessity of providing more effectually for the security of private rights, and the steady dispensation of Justice. Interferences with these were evils which had more perhaps than any thing else, produced this convention."66

\section{Exchanging Natural for Civil Rights}

As will be discussed at greater length below, the most important power surrendered to government is what John Locke and others called "the executive power" and what is sometimes called the "police power." This is the power to enforce or "police" one's rights when they have been violated by others. Indeed, Locke argued that it was the "inconvenience" of exercising the executive power in the state of nature that justified the creation of an "impartial magistrate" - that is, government.

The particular problem with individuals retaining the executive power is that they are then the judges in their own cases.

I easily grant, that Civil Government is the proper Remedy for the Inconveniences of the State of Nature, which must certainly be Great, where Men may be Judges in their own Case, since 'tis easily to be imagined, that he who was so unjust as to do his Brother an Injury, will scarce be so just as to condemn himself for it. ${ }^{67}$

When "surrendering" one's executive power to government, however, one receives in return a "civil" right to have one's retained liberty rights protected by the police power now in the hands of the civil government. This civil right to "the protection of the laws" is the root of the Equal Protection Clause of the Fourteenth Amendment, which

$66 \quad$ Id. at 76.

67 Locke, supra note 61, at 276. 
mandates that no state shall "deny to any person within its jurisdiction the equal protection of the laws." 68

Thus, in return for the surrendered natural right of enforcement, government assumes a positive obligation to protect the unsurrendered rights retained by the people. Those retained rights remain a measure of the propriety of government enforcement, since it is for their protection that the executive power is surrendered in the first instance. As Locke explained:

The Supream Power cannot take from any Man any part of his Property without his own consent. For the preservation of Property being the end of Government, and that for which Men enter into Society, it necessarily supposes and requires, that the People should have Property, without which they must be suppos'd to lose that by entring into Society, which was the end for which they entered into it, too gross an absurdity for any Man to own. ... Hence it is a mistake to think, that the Supreme or Legislative Power of any Commonwealth, can do what it will, and dispose of the Estates of the Subject arbitrar$i l y$, or take any part of them at pleasure. ${ }^{69}$

But even this account of exchanging natural for civil rights underestimates the role played by natural rights after persons enter into civil society.

\section{The Agency Theory of Government}

To understand better how delegated governmental powers can be squared with retained rights, those seeking historical context must also take into account the law governing agency relationships or what is still sometimes referred to as the law of "master and servant."70 The Founders were accomplished private lawyers, familiar with eighteenth century agency law and, not coincidentally, they also often professed their belief in the "agency theory" of government. The idea that government officials are the agents or servants and the people are the principals or masters, however quaint it may seem to political sophisticates today, was widely held. Benjamin Franklin articulated this popu-

68 U.S Const. amend. XIV, § 1; see also Steven J. Heyman, The First Duty of Government: Protection, Liberty and the Fourteenth Amendment, 41 Duke L.J. 507 (1991).

69 Locke, supra note 61, at 360-61.

70 The rhetoric of "master/servant" is today limited to doctrines governing employer-employee relationships and primarily for when employers are liable for the tortious acts of their employees, as opposed to when agents may bind their principals to contracts. See Harold Gill Reuschlein \& William A. Gregory, The Law of Agency ANd PARTNership 102 (2d ed. 1990) (“[A] servant is one who works physically for another, subject to the control of that other who is called a master."). 
lar view to the Constitutional Convention: "In free Governments the rulers are the servants, and the people their superiors \& sovereigns." 71

By definition, a principal "surrenders" certain powers to her agent. If I designate you my agent to sell my car, you now are in possession of the power to sell, which formerly only I possessed. It is even possible that I delegate my exclusive power to sell the car to you and that, by the terms of our agreement, I no longer may rightfully sell the car to a third party. Think of authors who routinely give an exclusive license to a publisher to publish an article or book, which the author may then not republish on his or her own.

Yet, just because certain powers (or rights) are delegated does not entail that the agent is now the master. For, according to agency law, the agent is to exercise those powers only (1) "on behalf of" and (2) "subject to the control of" the master or principal. ${ }^{72}$ Of course, the principal does not literally control the behavior of the agentthere would be no advantage to entering into a principal-agent relationship were that the case. Instead, the agent must yield to the control of the principal when the principal exerts it. And even when operating on his own, the agent must always exercise the powers delegated to him "on behalf" of the interests of the principal and can be held responsible for any breach of this fiduciary duty.

It would be more accurate and much neater if we were to speak not of rights delegated to government but only of powers. Unfortunately, language then, as now, is not always used with precision. Though it must be admitted that statements can be found that speak of alienated "rights" when "powers" would have been the better term, one thing is remarkable: The Framers of the Constitution were rigorously consistent in referring to the "powers" of government and to the "rights" of the people. The Constitution refers to powers-and only powers-being delegated to government, whereas rights are retained by the people (and powers reserved to them as well). The best theory of this usage is that only powers, not rights, are delegated to government and that all rights are retained by the people as a measure of the propriety of the exercise of governmental power.

\section{Regulating the Exercise of Inalienable Rights}

Then there is the matter of "inalienable" rights, that is, rights that cannot be surrendered. How can this concept be squared with statements about surrendering natural rights and the enactment of free-

71 Madison, supra note 48, at 371 (statement of Benjamin Franklin).

72 For a general overview of agency law, see Randy E. Barnett, Squaring Undisclosed Agency Law with Contract Theory, 75 CAL. L. Rev. 1969 (1987). 
dom-constraining laws? One way to understand this is to think of inalienable rights as somehow more fundamental or important than other trivial or trifling natural rights, and then posit that, while the latter can be surrendered and restricted, the former cannot. However, this formulation is misleading.

It is better to say that inalienable rights are more abstract than other specific natural rights or liberties. These inalienable abstract rights can be classified as the rights of several property, freedom of contract, self-defense, first possession, and restitution. ${ }^{73}$ Together, these rights define a boundary or jurisdictional space within which people should be free to make their own choices.

The specific choices people make within this jurisdictional space are the more particular "natural" rights or liberties. For example, the abstract and inalienable right to the possession, use, and enjoyment of several property includes the particular right to read a book in one's own house or to go to bed when one wishes, though such specific "trivial" rights are impossible to list and may themselves be alienated. Moreover, my inalienable property rights to the exclusive use and enjoyment of my body do not prevent me from waiving this right by consenting to get in the ring with Muhammad Ali.

It is common to see statements to the effect that one's right to do something is subject to the "laws of the land." For example, while Locke argued that one completely surrendered the executive power to enforce one's rights by punishing one's attacker or extracting reparations from him, he contended that one "gives up" the natural right of self-preservation "to be regulated by Laws made by the Society, so far forth as the preservation of himself, and the rest of that Society shall require." 74

Such statements raise the issue of the reasonable regulation of one's natural rights. Assume that there is a natural and inalienable right to possess, use, and dispose of several property. Suppose that someone wants to transfer her property rights in a tract of land to her son after her death so she executes a document called a "will." How this document will be interpreted and enforced in a court of law requires the articulation of certain rules or laws governing what constitutes a valid will. Requirements of formality, for example, may be devised specifying the need for two or more witnesses to a signature. Such rules or laws regularize will-making. The power to regulate will-

73 See generally Randy E. Barnett, The Structure of Liberty: Justice and the RulE OF LAW (1998) (defending these as the principal abstract natural rights because they address the pervasive social problems of knowledge, interest, and power).

74 LOCKE, supra note 61, at 352 (emphasis added). 
making in this sense does not, however, include the power to rewrite wills to contradict the demonstrable intent of the testator, nor the power to prohibit the making of wills altogether, nor the power to confiscate a percentage of the decedent's property in estate "taxes."

That the reasonable regulation of natural rights is essential to their efficacious exercise and enforcement in civil society does not entail that these rights are surrendered completely to the government. On the contrary, these rights remain the object and measure of any regulations. That is, the protection and facilitation of everyone's retained rights in civil society is the purpose of any "police" regulation by law, and this object or end is the measure of whether a particular regulation is or is not reasonable.

By this account, some natural rights can be surrendered to government in order to better secure those that are retained. As was said by Samuel Nasson, at the Massachusetts ratification convention: "When I give up any of my natural rights, it is for the security of the rest."75 But it is better to adopt the terminology of the Constitution itself and speak of (limited) powers being delegated by the peopleor principals or masters-to their servants or agents in government. The rights that are retained provide the measure of how these powers should be exercised. The "police power" to enforce or regulate a retained right is not the power to confiscate, prohibit, infringe, or abridge its exercise.

Locke made a similar point when he claimed that whatever liberty or powers are given up when one enters society are given up

only with an intention in every one the better to preserve himself his Liberty and Property; (For no rational Creature can be supposed to change his condition with the intention to be worse) the power of the Society, or Legislative constituted by them, can never be suppos'd to extend farther than the common good; but is obliged to secure every ones Property by providing against [the] ... defects ... that made the State of Nature so unsafe and uneasie. ${ }^{76}$

It is also worth noting that Locke distinguished the two powers that were given up, either entirely (the executive power) or to be regulated by law (the power of self-preservation), from a third species of natural rights that he does not claim a person surrenders either upon entering civil society or upon forming a government. This third spe-

752 Elliot's Debates, supra note 43 , at 134 (statement by Samuel Nasson at the Massachusetts convention, Feb. 1, 1788).

76 Locke, supra note 61 , at 353. 
cies is "the liberty he has of innocent Delights."77 Provided that such pleasures do not unjustly interfere with the rights of others, the civil authority has no role in the prohibition or even the regulation of "innocent Delights."

Few who caution us against taking the Founders' expressed commitment to natural rights out of context address the views of those who wrote the Fourteenth Amendment. Even if their commitment to natural rights was more "liberal" and less "republican" than the Founders', it is they-not the Founders-who wrote the Fourteenth Amendment. When we consider the protections of "privileges or immunities" provided by the Fourteenth Amendment, it is their conception-not the Founders' - that represents the original meaning of that phrase.

\section{The Original Meaning of the Privileges or Immunities Clause}

The conception of natural rights as liberty rights that may sometimes be regulated but not abolished was not abandoned after the founding period. It was held, perhaps even to a greater degree, by the framers of the Fourteenth Amendment. Recall John Page's reference to "privilege" in his discussion of the right of peaceable assembly that became part of the First Amendment. ${ }^{78}$ The terms "rights," "liberties," "privileges," and "immunities" were often used interchangeably or in a cluster. This terminology is reflected in what is known as the Privileges or Immunities Clause of the Fourteenth Amendment, adopted in the wake of the Civil War: "No state shall make or enforce any law which shall abridge the privileges or immunities of citizens of the United States . . .."79

The Fourteenth Amendment was enacted to ensure the constitutionality of the Civil Rights Bill of 1866 and to prevent future Congresses from reneging on its guarantees. ${ }^{80}$ The bill provided federal protections against infringement by state governments of the rights "to make and enforce contracts, to sue, be parties, and give evidence, to inherit, purchase, lease, sell, hold, and convey real and personal property, and to full and equal benefit of all laws and proceedings for the security of person and property." 81

77 Id. at 352 ("For in the State of Nature, to omit the liberty he has of innocent Delights, a Man has two Powers.").

78 See supra note 54 and accompanying text.

79 U.S. Const. amend. XIV, $\$ 1$.

80 See Michael Kent Curtis, No State Shall Abridge: The Fourteenth AmendMENT AND THE Bill OF Rights 71-91 (1986) (outlining the congressional debates on the Civil Rights Bill and the Fourteenth Amendment).

81 See Act of April 9, 1866, ch. 31, § 1, 14 Stat. 27, 27. 
As Michael Kent Curtis has shown, "privileges or immunities" was a common way of referring to "civil rights," which included the legally protected rights one received in return for surrendering to the government the natural right, or "executive power," to enforce one's own rights.

Both in his prototype and in his final version of the Fourteenth Amendment, [Senator John A.] Bingham used the words privileges and immunities as a shorthand description of fundamental or constitutional rights. Use of the words in this way had a long and distinguished heritage. Blackstone's Commentaries on the Laws of England, published in the colonies on the eve of the Revolution, had divided the rights and liberties of Englishmen into those "immunities" that were the residuum of natural liberties and those "privileges" that society had provided in lieu of natural rights. ${ }^{82}$

If the framers of the Fourteenth Amendment meant to protect natural rights-or even civil rights-why did they use the term "privileges or immunities" instead? The short answer is that they did so because, while "privileges or immunities" include natural rights, it is a broader phrase that includes additional rights.

To appreciate this, we must begin by considering what was then a controversial interpretation of Article IV, Section 2 of the original Constitution: "The Citizens of each State shall be entitled to all Privileges and Immunities of Citizens in the several States."83 From the earliest days of the United States some argued that this provision referred to the fundamental or natural rights that belonged to every citizen of the United States. That this was truly the original meaning of the Privileges and Immunities Clause in Article IV has been contested. ${ }^{84}$ It is not seriously disputed, however, that some time after ratification it came to be widely insisted by some judges, scholars, and opponents of slavery that Article IV was indeed a reference to natural rights. Nor is it disputed that, whenever it first developed, the members of the Thirty-Ninth Congress meant to import this meaning into

82 Curtis, supra note 80 , at 64 (emphasis added).

83 U.S. Const. art. IV, § 2.

84 Compare Chester James Antieau, Paul's Perverted Privileges or the True Meaning of the Privileges and Immunities Clause of Article Four, 9 WM. \& MARY L. REv. 1 passim (1967) (contending that the clause referred to natural rights), with David S. Bogen, The Privileges and Immunities Clause of Article IV, 37 CASE W. REs. L. REv. 794, 796 (1987) (arguing that the clause was "not a reference to natural law, but was solely concerned with creating a national citizenship"). In accord with Antieau is Michael Conant, $A n$ timonopoly Tradition Under the Ninth and Fourteenth Amendments: Slaughter-House Cases Re-Examined, 31 ЕмоRY L.J. 785, 817 (1982). 
the text of the Constitution by using the language of "privileges" and "immunities" in the Fourteenth Amendment. ${ }^{85}$

The antebellum argument that privileges and immunities included natural rights was made famously in 1823 by Justice Bushrod Washington, while sitting as a circuit court trial judge in the case of Corfield $v$. Coryell. ${ }^{86}$ Because this language was so often repeated by those seeking to find federal protection of fundamental rights, especially by members of the Thirty-Ninth Congress, I present it in full:

The inquiry is, what are the privileges and immunities of citizens in the several states? We feel no hesitation in confining these expressions to those privileges and immunities which are, in their nature, fundamental; which belong, of right, to the citizens of all free governments; and which have, at all times, been enjoyed by the citizens of the several states which compose this Union, from the time of their becoming free, independent, and sovereign. What these fundamental principles are, it would perhaps be more tedious than difficult to enumerate. They may, however, be all comprehended under the following general heads: Protection by the government; the enjoyment of life and liberty, with the right to acquire and possess property of every kind, and to pursue and obtain happiness and safety; subject nevertheless to such restraints as the government may justly prescribe for the general good of the whole. The right of a citizen of one state to pass through, or to reside in any other state, for purposes of trade, agriculture, professional pursuits, or otherwise; to claim the benefit of the writ of habeas corpus; to institute and maintain actions of any kind in the courts of the state; to take, hold and dispose of property, either real or personal; and an exemption from higher taxes or impositions than are paid by the other citizens of the state; may be mentioned as some of the particular privileges and immunities of citizens, which are clearly embraced by the general description of privileges deemed to be fundamental: to which may be added, the elective franchise, as regulated and established by the laws or constitution of the state in which it is to be exercised. These, and many others which might be mentioned, are,

85 This is conceded even by those who deny that the original meaning of "privileges and immunities" in Article IV was a reference to natural rights. See Bogen, supra note 84 , at 843 :

This array of arguments [that the clause referred to natural rights] proved persuasive to a generation confronted with the moral breakdown of society represented by slavery. Slavery was constitutional, but contrary to fundamental principles of natural law. The symbolic honor and integrity of the Constitution could be saved by identifying it with fundamental rights. This the framers of the fourteenth amendment attempted to do in the privileges and immunities clause of that amendment.

866 F. Cas. 546 (C.C.E.D. Pa. 1832) (No. 3230). 
strictly speaking, privileges and immunities, and the enjoyment of them by the citizens of each state, in every other state, was manifestly calculated (to use the expressions of the preamble of the corresponding provision in the old articles of confederation) "the better to secure and perpetuate mutual friendship and intercourse among the people of the different states of the Union."87

While this passage includes reference to what were considered natural or inherent liberty rights, "privileges and immunities" here unquestionably refers also to such positive civil rights as the "protection of government" that one receives in exchange for surrendering one's power of enforcement. As employed by Justice Washington, it is a broader term that also includes other fundamental rights created by state and federal constitutions, such as "the elective franchise, as regulated and established by the laws or constitution of the state in which it is to be exercised." 88

Chester Antieau observed that "it would be almost impossible to overestimate the importance of the above quotation upon American law." 89 Of greatest relevance, Corfield was repeatedly cited by some members of the Thirty-Ninth Congress as constitutional justification for their passing the Civil Rights Act of 1866, which provided in section 1 that

[S] uch citizens, of every race and color, without regard to any previous condition of slavery ... shall have the same right, in every State and Territory in the United States, to make and enforce contracts, to sue, be parties, and give evidence, to inherit, purchase, lease, sell, hold, and convey real and personal property, and to full and equal benefit of all laws and proceedings for the security of person and property, as is enjoyed by white citizens . . . ${ }^{90}$

Most, if not all, of the rights on this list are unenumerated liberty rights of the sort accepted at the Founding.

Senator Lyman Trumbell, a former justice of the Illinois Supreme Court, was the principal draftsman of both the Thirteenth Amendment prohibiting involuntary servitude and the Civil Rights Act of 1866. As chairman of the Senate Judiciary Committee, he took the floor of the Senate to argue that Congress had the authority to pass the Civil Rights Act under, among other provisions, the Privileges and

87 Id. at 551-52.

88 Whether the right to vote was among the privileges or immunities protected by the Fourteenth Amendment later became a matter of some controversy. But there is little doubt that the right to a jury trial, though not a natural right, was considered a privilege or immunity of citizenship by the authors of the Fourteenth Amendment.

89 Antieau, supra note 84, at 12.

90 Act of April 9, 1866, ch. 31, § 1, 14 Stat. 27, 27. 
Immunities Clause of Article IV: "What rights are secured to the citizens of each State under that provision? Such fundamental rights as belong to every free person." 91 To establish this interpretation, he cited several judicial opinions and then offered, in its entirety, the quotation from Washington's opinion in Corfield that appears above. ${ }^{92}$

In another speech advocating the override of President Johnson's veto of the Civil Rights Act, Trumbell posed the question, "[w]hat rights do citizens of the United States have?" He answered, "They are those inherent, fundamental rights which belong to free citizens or free men in all countries, such as the rights enumerated in this bill, and they belong to them in all the States of the Union." ${ }^{33}$ As examples of "natural rights" and "inalienable rights" he offered these: "The right of personal security, the right of personal liberty, and the right to acquire and enjoy property. " 94

Along the same lines was the speech by Representative James F. Wilson of Iowa, who was coauthor of the Thirteenth Amendment, manager of the Civil Rights Bill in the House, and chairman of the House Judiciary Committee. Wilson argued that "civil rights are the natural rights of man; and these are the rights which this bill proposes to protect every citizen in the enjoyment of throughout the entire dominion of the Republic." ${ }^{95}$ After elaborating at length on these rights, he concluded, "Before our Constitution was formed, the great fundamental rights which I have mentioned, belonged to every person who became a member of our great national family. No one surrendered a jot or tittle of these rights by consenting to the formation of the Government." ${ }^{96}$ Without "the power . . . to secure these rights which existed anterior to the ordination of the Constitution," the government would be "a failure in its most important office." 97

After the Civil Rights Bill was vetoed by President Johnson on the ground that it exceeded the constitutional powers of Congress, Representative William Lawrence, Republican of Ohio and a former state court judge, rose to advocate overriding that veto. After a lengthy examination of the authorities on behalf of the proposition that "[1] egislative powers exist in our system to protect, not to destroy, the inalienable rights of men," 98 Lawrence noted that "[i]t has never been

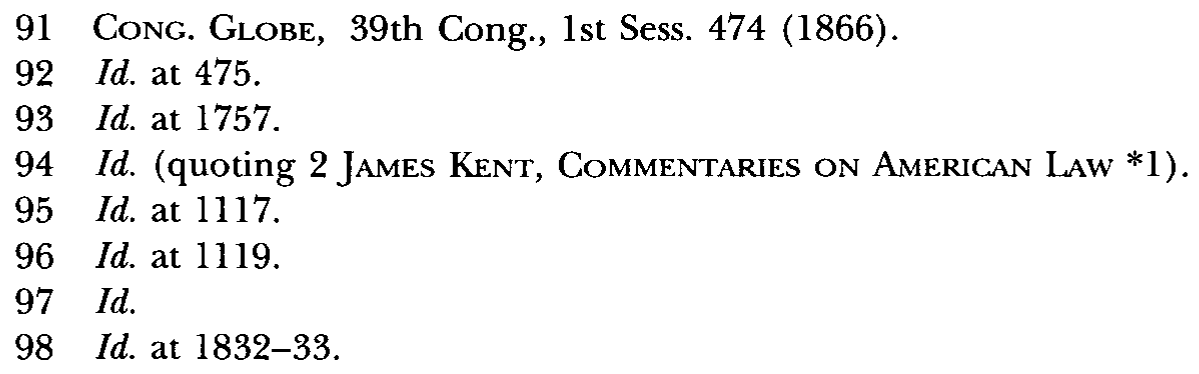


deemed necessary to enact in any constitution or law that citizens should have the right to life or liberty or the right to acquire property. These rights are recognized by the Constitution as existing anterior to and independently of all laws and all constitutions." ${ }^{99}$ He concluded: "Without further authority I may assume, then, that there are certain absolute rights which pertain to every citizen, which are inherent, and of which a State cannot constitutionally deprive him."100

Lawrence also cited with approval Justice Washington's opinion in Corfield, while elaborating that though " $[t]$ he Constitution does not define what these privileges and immunities" in Article IV are, they "are of two kinds, to wit, those which I have shown to be inherent in every citizen of the United States, and such others as may be conferred by local law and pertain only to the citizen of the State."101 This statement by Representative Lawrence confirms that "privileges or immunities" was a reference both to inherent or natural rights and to various rights or privileges created by the positive law of particular governments.

As important to understanding the original meaning of the term "privileges or immunities" were the explanations later offered by members of Congress when discussing the Fourteenth Amendment. After reading the same quotation from Justice Washington's opinion in Corfield, Senator Jacob Howard, Republican and former Attorney General of Michigan, stated: "Such is the character of the privileges and immunities spoken of in the second section of the fourth article of the Constitution." 102 He then continued: "To these privileges and immunities, whatever they may be-for they are not and cannot be fully defined in their entire extent and precise nature-to these should be added the personal rights guaranteed and secured by the first eight amendments of the Constitution."103

After listing these rights, ${ }^{104}$ Howard noted the fact that courts had rejected the abolitionist argument that the Privileges and Immunities Clause of Article IV protected the rights of citizens from infringement by state governments.

[I] $t$ is a fact well worthy of attention that the course of decision of our courts and the present settled doctrine is, that all these immunities, privileges, rights, thus guarantied by the Constitution or recognized by it, are secured to the citizen solely as a citizen of the United

99 Id. at 1833.

$100 \quad I d$.

101 Id. at 1836.

$102 I d$. at 2765.

103 Id.

104 Id. (including the "personal" right "to keep and to bear arms"). 
States and as a party in their courts. They do not operate in the slightest degree as a restraint or prohibition upon State legislation. States are not affected by them . . . ${ }^{105}$

Thus the need for the Privileges or Immunities Clause of the Fourteenth Amendment:

Now, sir, there is no power given in the Constitution to enforce and to carry out any of these guarantees . . . but they stand simply as a bill of rights in the Constitution, without power on the part of Congress to give them full effect; while at the same time the States are not restrained from violating the principles embraced in them except by their own local constitutions, which may be altered from year to year. The great object of the first section of this amendment is, therefore, to restrain the power of the States and compel them at all times to respect these great fundamental guarantees. ${ }^{106}$

The same sentiment was expressed by Congressman Frederick Woodbridge, Republican of Vermont. The "object of the proposed amendment," he said, was to give "the power to Congress to enact those laws which will give to a citizen of the United States the natural rights which necessarily pertain to citizenship," or, in other words, "those privileges and immunities which are guaranteed to him under the Constitution of the United States." 107 That this represented a substantial change in the relationship between state and federal governments is difficult to overemphasize.

Those who seek to diminish the significance of the Privileges or Immunities Clause have argued that, because it was enacted to constitutionalize the Civil Rights Bill of 1866, the amendment only protects against discrimination among the citizens of a state, the way the Privileges and Immunities Clause prohibits discrimination against out-ofstaters. The amendment does not say this, however, and there is little if any evidence its original meaning was so limited. Instead it adopts language that prohibits states from abridging the privileges or immunities of some of its citizens or all of its citizens. In this way the clause protects rights both from discriminatory laws, as well as from laws that violate rights "absolutely" or across the board.

Still, the Civil Rights Bill of 1866 is relevant to confirming the substance of privileges or immunities. For, notwithstanding that the bill sought to protect blacks by holding states to the protection afforded the rights of whites, the fact remains that most of the "privileges or immunities" protected by this statute were natural liberty

$105 I d$.

106 Id. at 2765-66 (emphasis added).

107 Id. at 1088 (emphasis added). 
rights. Those who try to limit the Fourteenth Amendment to the very different words of the Civil Rights Bill are wrong. And they typically fail to see how the proper connection of the Civil Rights Bill to the Fourteenth Amendment precludes the crabbed interpretation of these privileges or immunities that was adopted by the Supreme Court within five years of its enactment over the ringing dissents of four Justices.

I have seen little in the historical record to suggest exactly how the rights "retained by the people" referred to in the Ninth Amendment compared with the "privileges or immunities" protected by the Fourteenth. The natural implication is that because both phrases originally referred to background, natural, or inherent rights, both provisions refer to the same set of unenumerable rights, though they differ on the jurisdiction created for the protection of these rights. Just as the Fourteenth Amendment extended protection of the enumerated rights of the first eight amendments to violations by state governments, so too did it extend federal protection of the preexisting unenumerated rights "retained by the people." The quotations from Justice Washington and others suggest that "privileges or immunities" is a broader term including both natural or inherent rights as well as those particular "positive" procedural rights created by the Bill of Rights.

This was the view held by Ohio Senator John Sherman, a Republican member of the Thirty-Ninth Congress and future Secretary of State who, some years after the ratification of the Fourteenth Amendment, pointed to the Ninth Amendment as evidencing the existence of "other rights beyond those recognized"108 in the Bill of Rights. Speaking to the Senate in $\mathbf{1 8 7 2}$ in support of a civil rights bill to guarantee blacks and other citizens equal access to public accommodations-rights nowhere mentioned in the Constitution-Sherman contended:

[T] he ordinary rights of citizenship, which no law has ever attempted to define exactly, the privileges, immunities, and rights, (because I do not distinguish between them, and cannot do it), of citizens of the United States, such as are recognized by the common law, such as are ingrafted in the great charters of England, some of them in the constitutions of different States, and some of them in the Declaration of Independence, our fathers did not attempt to enumerate. They expressly said in the ninth amendment that they would not attempt to enumerate these rights; they were innumera-

108 Cong. Globe, 42d Cong., 2d Sess. app. at 26 (1872) (statement of Sen. John Sherman). 
ble, depending upon the laws and the courts as from time to time administered. ${ }^{109}$

Sherman conceded that " $[\mathrm{t}]$ here may be sometimes great dispute and doubt as to what is the right, immunity, or privilege conferred upon a citizen of the United States." 110 Nevertheless, the task of identifying that right must fall "from time to time [to] the judicial tribunals." 111 To determine these rights, immunities, or privileges, judges

will look first at the Constitution of the United States as the primary fountain of authority. If that does not define the right they will look for the unenumerated powers to the Declaration of American Independence, to every scrap of American history, to the history of England, to the common law of England, the old decisions of Lords Mansfield and Holt, and so on back to the earliest recorded decisions of the common law. There they will find the fountain and reservoir of the rights of American as well as English citizens. ${ }^{112}$

Sherman advocated his expansive, perhaps overly expansive, reading of the Privileges or Immunities Clause in 1872. Little did he know that this flywheel of the Fourteenth Amendment was about to be excised and the amendment redacted by a bare majority of the Supreme Court.

\section{The Demise of the Privileges or Immunities Clause}

When the meaning of the Privileges or Immunities Clause was considered by the Supreme Court, its original meaning was set aside

109 Id. at 844 (statement of Sen. John Sherman).

$110 I d$.

111 Id.

112 Id. Senator Allen Thurman, an Ohio Democrat and former member of the Ohio Supreme Court, agreed with Sherman that the retained rights referred to in the Ninth Amendment are held by the people

against the Government of the United States by as good a title as they hold them against the world. They belong to them as people or as individuals. They have never surrendered them to any Government, and they do not hold them by the grace of any Government whatsoever; they hold them because they were and are their inherent natural rights which have never been surrendered.

Id. app. at 26. Nevertheless, Thurman also contended that these are not rights the people hold "as citizens of the United States, but so to speak, in despite of the United States." Id. Thurman was also concerned with the indefiniteness of identifying such extratextual rights. "Where are we to find a definition of them?" he asked. Id. "The Senator from Massachusetts finds the definition in the Declaration of Independence; another Senator finds it in something else; and so on to the end of the chapter; and we have nothing certain, nothing definite, nothing upon which any man can rely." Id. 
by a five to four decision in what are called the Slaughter-House Cases. ${ }^{113}$ It is very useful to revisit the opinions in these cases, both to see the weakness of the majority's reasoning, and to examine carefully the theories set forth in three separate dissents. These much neglected dissenting opinions tell us a great deal about how the Privileges or Immunities Clause was supposed to work. And this, in turn, will help us discern the proper scope of the police powers of states.

The Slaughter-House Cases arose when, in 1869, the legislature of Louisiana passed an act ordering all animals imported for consumption in the city to be landed at certain places, and all intended for food to be slaughtered there. The same law also conferred on seventeen persons the exclusive right to maintain landings for cattle and to erect slaughterhouses, chartering them under the name of The Crescent City Live-Stock Landing and Slaughter-House Company. This law was challenged by the Live Stock Dealers' and Butchers' Association, whose members would be prohibited from competing with the new monopoly.

At the appellate court level, Supreme Court Justice Bradley, sitting as a circuit court judge, ${ }^{114}$ indicated sympathy for a constitutional challenge based on the Privileges or Immunities Clause (although he ruled that the federal courts did not have power to enjoin state proceedings initiated by the Crescent City Company). Bradley began by distinguishing the new Privileges or Immunities Clause of the Fourteenth Amendment from the old Privileges and Immunities Clause of Article IV. ${ }^{115}$ The new provision "is not identical with the clause in the constitution which declared that 'the citizens of each state shall be entitled to all privileges and immunities of citizens in the several states.' It embraces much more."116 The "Privileges and Immunities" referred to in Article IV "were only such as each state gave to its own citizens. Each was prohibited from discriminating in favor of its own citizens, and against the citizens of other states."117 But the Privileges or Immunities Clause of the Fourteenth Amendment "prohibits any state from abridging the privileges or immunities of the citizens of the United States, whether its own citizens or any others. It not merely

11383 U.S. (16 Wall.) 36 (1872).

114 In those days before the creation of the Circuit Courts of Appeals, Justices themselves "rode circuit" to hear appeals.

115 In what follows, I use "Privileges or Immunities Clause," to refer to the clause in the Fourteenth Amendment. When I refer to "Privileges and Immunities Clause," I mean the clause that appears in Article IV.

116 Live-Stock Dealers' \& Butchers' Ass'n v. Crescent City Live-Stock Landing \& Slaughter-House Co., 15 F. Cas. 649, 652 (C.C.D. La. 1870) (No. 8408).

117 Id. 
requires equality of privileges; but it demands that the privileges and immunities of all citizens shall be absolutely unabridged, unimpaired."118

In other words, while the Privileges and Immunities Clause of Article IV barred discrimination against out-of-staters, the Privileges or Immunities Clause of the Fourteenth Amendment barred states both from discriminating among different citizens within a state and from abridging or impairing of the rights of all citizens even if the restrictions applied equally to all. Bradley then addressed the nature of these privileges a state cannot invade. "It may be difficult to enumerate or define them," he began,

[b] ut so far as relates to the question in hand, we may safely say it is one of the privileges of every American citizen to adopt and follow such lawful industrial pursuit-not injurious to the community-as he may see fit, without unreasonable regulation or molestation, and without being restricted by any of those unjust, oppressive, and odious monopolies or exclusive privileges which have been condemned by all free governments .... ${ }^{119}$

According to Justice Bradley, this and other essential privileges cannot be invaded without sapping the very foundations of republican government. A republican government is not merely a government of the people, but it is a free government. Without being free, it is republican only in name, and not republican in truth, and any government which deprives its citizens of the right to engage in any lawful pursuit, subject only to reasonable restrictions, or at least subject only to such restrictions as are reasonably within the power of government to impose,-is tyrannical and unrepublican. And if to enforce arbitrary restrictions made for the benefit of a favored few, it takes away and destroys the citizen's property without trial or condemnation, it is guilty of violating all the fundamental privileges to which I have referred, and one of the fundamental principles of free government. ${ }^{120}$

When the various slaughterhouse cases finally made their way to the full Supreme Court, Bradley's approach was rejected by a vote of five to four. Writing for the majority, Justice Miller distinguished between the privileges and immunities of national citizenship, which were created by the Constitution and protected by the Fourteenth Amendment, and the privileges and immunities or "civil rights" of state citizenship, which corresponded to what Justice Washington

$118 I d$.

$119 I d$.

$120 I d$. 
wrote in Corfield and were protected by the Privileges and Immunities clause of Article IV. ${ }^{121}$ The latter "are those which belong to citizens of the States as such, and ... they are left to the State governments for security and protection, and not by this article placed under the special care of the Federal government . . .."122

In defense of this interpretation, Miller offered no direct evidence from the statements of those who proposed the Fourteenth Amendment. Such proof would have been impossible. Instead, he ignored the original meaning of the clause to rest his conclusion on the consequences of holding otherwise. If the "privileges or immunities" protected by the Fourteenth Amendment were as broad as the category of "civil rights," he contended, then

not only are these rights subject to the control of Congress whenever in its discretion any of them are supposed to be abridged by State legislation, but that body may also pass laws in advance, limiting and restricting the exercise of legislative power by the States, in their most ordinary and usual functions, as in its judgment it may think proper on all such subjects. ${ }^{123}$

This, argued Miller, would be to give Congress a national police power that would supersede the traditional powers of the states in every area of legislation and would "radically change [ ] the whole theory of the relations of the State and Federal governments to each other and of both these governments to the people." 124 "[I]n the absence of language which expresses such a purpose too clearly to admit of doubt," 125 Miller concluded that "no such results were intended by the Congress which proposed these amendments, nor by the legislatures of the States which ratified them." 126 Because the privilege to pursue one's trade or occupation was a "civil right" and not a privilege of national citizenship it was, therefore, unprotected by the Fourteenth Amendment.

What then, according to Justice Miller, were the privileges and immunities of national citizenship protected by the amendment? $\mathrm{He}$ declined to elaborate since it was clear to him that the right asserted by the claimants was not among them. But he did list a few "which owe their existence to the Federal government, its National character, its Constitution, or its laws." 127 A citizen has the right

\footnotetext{
121 Slaughter-House Cases, 83 U.S. (16 Wall.) 36, 78 (1872).

$122 I d$.

123 Id.

$124 I d$.

125 Id

126 Id.

127 Id. at 79.
} 
to come to the seat of government to assert any claim he may have upon that government, to transact any business he may have with it, to seek its protection, to share its offices, to engage in administering its functions. He has the right of free access to its seaports, through which all operations of foreign commerce are conducted, to the subtreasuries, land offices, and courts of justice in the several States. . . .

Another privilege of a citizen of the United States is to demand the care and protection of the Federal government over his life, liberty, and property when on the high seas or within the jurisdiction of a foreign government. ... The right to peaceably assemble and petition for redress of grievances, the privilege of the writ of habeas corpus, are rights of the citizen guaranteed by the Federal Constitution. The right to use the navigable waters of the United States, however they may penetrate the territory of the several States, all rights secured to our citizens by treaties with foreign nations, are dependent upon citizenship of the United States, and not citizenship of a State. ${ }^{128}$

The dissenting justices, in separate opinions, took strong issue with Miller's imputation of intent to Congress. On the majority's interpretation, wrote Justice Field, "it was a vain and idle enactment, which accomplished nothing, and most unnecessarily excited Congress and the people on its passage. . . . But if the amendment refers to the natural and inalienable rights which belong to all citizens, the inhibition has a profound significance and consequence."129 What, then, did Field think were the privileges or immunities that were secured against abridgment by state legislation? Field's answer rested importantly on evidence of original meaning.

First, privileges or immunities included the civil rights protected by the Civil Rights Act: "the right 'to make and enforce contracts, to sue, be parties and give evidence, to inherit, purchase, lease, sell, hold, and convey real and personal property, and to full and equal benefit of all laws and proceedings for the security of person and property." "130 He also referenced the list recited by Justice Washington in Corfield:

Mr. Justice Washington said he had "no hesitation in confining these expressions to those privileges and immunities which were, in their nature, fundamental; which belong of right to citizens of all free governments, and which have at all times been enjoyed by the citizens of the several States which compose the Union, from the

\footnotetext{
$128 I d$. at 79-80 (quotation omitted).

$129 I d$. at 96 (Field, J., dissenting).

130 Id. (Field, J., dissenting).
} 
time of their becoming free, independent, and sovereign;" and, in considering what those fundamental privileges were, he said that perhaps it would be more tedious than difficult to enumerate them, but that they might be "all comprehended under the following general heads: protection by the government; the enjoyment of life and liberty, with the right to acquire and possess property of every kind, and to pursue and obtain happiness and safety, subject, nevertheless, to such restraints as the government may justly prescribe for the general good of the whole." 131

To Justice Field, this appeared "to be a sound construction of the clause in question. The privileges and immunities designated are those which of right belong to the citizens of all free governments." 132 Unlike Miller, Field referred to the congressional debates, noting that

repeated reference was made to this language of Mr. Justice Washington. It was cited by Senator Trumbull with the observation that it enumerated the very rights belonging to a citizen of the United States set forth in the first section of the act, and with the statement that all persons born in the United States, being declared by the act citizens of the United States, would thenceforth be entitled to the rights of citizens, and that these were the great fundamental rights set forth in the act; and that they were set forth "as appertaining to every freeman." 133

In essence, the majority found there to be two classes of privileges and immunities: national and state. The national ones were those specifically designated in the Constitution or directly derivable from its national character; the state ones were the full panoply of natural or "civil rights" that pertain to all free persons. The Privileges or Immunities Clause of the Fourteenth Amendment protects the former absolutely, while the Privileges and Immunities Clause of Article IV protects the latter by protecting citizens from discrimination when they are residing or acting in other states. In contrast, Justice Field contended that there was just one set of privileges and/or immunities that formerly had been unprotected from state infringement, but which had been given national protection by the enactment of the Fourteenth Amendment. As between the two, the dissenters' position is clearly more consonant with the origins and original meaning of the Privileges or Immunities Clause.

Like Justice Field's opinion, which discussed the original meaning of "privileges or immunities," Justice Bradley's dissenting opinion elaborated the arguments he had made earlier while riding circuit

131 Id. at 97 (Field, J., dissenting).

132 Id. (Field, J., dissenting).

133 Id. at 98 (Field, J., dissenting). 
concerning the meaning of this phrase, and again quoted Justice Washington's opinion in Corfield. But Bradley also offered an important theoretical rebuttal to Justice Miller's contention that equating "privileges or immunities" with civil rights would be to establish a broad national power that would supersede those of the states.

The right of a State to regulate the conduct of its citizens is undoubtedly a very broad and extensive one, and not to be lightly restricted. But there are certain fundamental rights which this right of regulation cannot infringe. It may prescribe the manner of their exercise, but it cannot subvert the rights themselves. ${ }^{134}$

In this neglected passage, Justice Bradley made a crucial distinction I mentioned above: the distinction between regulating the exercise of a civil right and improperly subverting or abridging its exercise; or between "regulating and facilitating" rightful conduct and "prohibiting or discouraging" it. States were free to regulate civil rights-that is, specify "the manner of their exercise"-and Congress was not empowered by the Fourteenth Amendment to do so. What the amendment did was to give the national government jurisdiction to protect these civil rights from being improperly abridged or subverted in the name of the "right of regulation." In the last portion of his dissent, Justice Bradley examined whether the monopoly at issue in the Slaughter-House Cases was a reasonable regulation and concluded that it was not.

Justice Bradley also offered a useful distinction between the Fourteenth Amendment's Privileges or Immunities Clause and its Due Process Clause. Among the most fundamental privileges or immunities protected by both provisions were those described by Blackstone as that of life, liberty, and property, and by the Declaration of Independence as that of life, liberty, and the pursuit of happiness.

These are the fundamental rights which can only be taken away by due process of law, and which can only be interfered with, or the enjoyment of which can only be modified, by lawful regulations necessary or proper for the mutual good of all; and these rights, I contend, belong to the citizens of every free government. ${ }^{135}$

The function of the Due Process Clause can be seen as prohibiting a state from depriving particular individuals, whether citizens or not, of their life, liberty, or property ("Nor shall the state deprive any person..."). ${ }^{136}$ The function of the Privileges or Immunities Clause is to protect the citizenry as a whole against unnecessary or improper

$134 I d$. at 114 (Bradley, J., dissenting) (emphasis added).

135 Id. at 116 (Bradley, J., dissenting) (emphasis added).

136 U.S. Const. amend. XIV, \& 1 (emphasis added). 
legislation that infringes upon the exercise of their civil rights or liberty ("No state shall make or enforce any law ..."). ${ }^{137}$ In other words, under the Due Process Clause of the Fourteenth Amendment, one cannot have his or her rights taken away without due process of law. And under the Privileges or Immunities Clause, Justice Bradley would require that legislation that purported to "regulate" or modify the exercise of any civil right-including that to life, liberty, and propertybe both necessary and proper for the common good.

In this way, Justice Bradley resolved an obvious and long-standing tension between the two provisions. If the Privileges or Immunities Clause is read to protect the rights found in the Bill of Rights, how is it that states may not abridge such rights as the right peaceably to assemble, but may abridge what appears to be the even more fundamental rights to life, liberty, and property on condition only that "due process" is provided? The answer is (1) that the Privileges or Immunities Clause includes the rights of life, liberty, and property in addition to those listed in the Bill of Rights, and (2) that legislation that improperly "abridges"-rather than regulates-the entire set of civil rights is prohibited, whereas even a proper law ${ }^{138}$ may not be used to deprive any particular person of her life, liberty, or property unless she is accorded due process. Whereas the Privileges or Immunities Clause protects a broad set of rights-including life, liberty, and propertyof all citizens from improper laws, the Due Process Clause protects the life, liberty, or property of all persons from an improper application of an otherwise proper law. ${ }^{139}$

Bradley also responded to Justice Miller's claim that providing federal protection of fundamental civil rights would bring into federal courts the full panoply of cases now decided by state courts. "As the privileges and immunities protected are only those fundamental ones which belong to every citizen, they would soon become so far defined as to cause but a slight accumulation of business in the Federal courts. Besides, the recognized existence of the law would prevent its frequent violation." ${ }^{140}$ By placing so much weight on consequences, the

137 Id. (emphasis added).

138 A proper law is one that either regulates rightful or prohibits wrongful behavior.

139 Because citizens may have more privileges than aliens, a law may treat them differently and still be proper under the Privileges or Immunities Clause-though citizens from other states are protected against discrimination within a state by the Privileges and Immunities Clause of Article IV. Nevertheless, all persons, whether or not they are citizens, have a right under the Due Process Clause to have otherwise proper laws applied to them with due process.

140 Slaughter-House Cases, 83 U.S. (16 Wall.) at 124 (Bradley, J., dissenting) 
majority was, thought Bradley, putting the cart before the horse. "The great question is, What is the true construction of the amendment? When once we find that, we shall find the means of giving it effect. The argument from inconvenience ought not to have a very controlling influence in questions of this sort." 141

Justice Miller's majority opinion has long been thought to have gutted the Privileges or Immunities clause of any real significance and, indeed, after Slaughter-House it ceased to play any important function. On the other hand, as has been pointed out by Kevin Newsom, Miller's opinion can be interpreted (though it has not been) as adopting the middle ground of protecting all the rights explicitly protected in the Constitution-including the Bill of Rights-but not the "civil rights" that are unmentioned there. ${ }^{142}$ The majority opinion's reference to the right in the First Amendment to peaceably assemble as a protected privilege or immunity of national citizenship supports Newsom's interpretation of the case. If Newsom is right, then the butchers lost because the right they asserted was not among those that were enumerated in the Constitution.

While a significant advance over the prevailing view of SlaughterHouse, even this more expansive interpretation of Miller's opinion conflicts with the original meaning of "privileges or immunities." As we have seen, the framers of the Fourteenth Amendment, and its supporters in Congress, spoke often of protecting the Bill of Rights from infringement by states, but they clearly did not limit the meaning of this clause to these rights. They repeatedly referred to Justice Washington's expansive list of rights in Corfield, to the concept of natural or "civil" rights, in addition to the privileges contained in the Bill of Rights. Among these additional privileges or immunities rights were the rights listed in the Civil Rights Act of 1866. And they made no distinction whatever between classes of state and national privileges or immunities.

In his dissenting opinion, the third of the three dissents filed in the case, Justice Swayne made much the same originalist point:

The construction adopted by the majority of my brethren is, in my judgment, much too narrow. It defeats, by a limitation not anticipated, the intent of those by whom the instrument was framed and of those by whom it was adopted. To the extent of that limitation it turns, as it were, what was meant for bread into a stone. By the Constitution, as it stood before the war, ample protection was given

141 Id. (Bradley, J., dissenting).

142 See Kevin Christopher Newsom, Setting Incorporationism Straight: A Reinterpretation of the Slaughter-House Cases, 109 YALE L.J. 643, 706 (2000). 
against oppression by the Union, but little was given against wrong and oppression by the States. That want was intended to be supplied by this amendment. Against the former this court has been called upon more than once to interpose. Authority of the same amplitude was intended to be conferred as to the latter. But this arm of our jurisdiction is, in these cases, stricken down by the judgment just given. Nowhere, than in this court, ought the will of the nation, as thus expressed, to be more liberally construed or more cordially executed. This determination of the majority seems to me to lie far in the other direction. ${ }^{143}$

Swayne concluded by expressing his earnest "hope that the consequences to follow may prove less serious and far-reaching than the minority fear they will be."144

The Fourteenth Amendment was born of a newfound distrust of state governments. The immediate cause of this distrust was, of course, the imposition of chattel slavery by state governments in the South before the war and the resistance to reconstruction afterward. But while it was instigated by the experience of reconstruction, the Fourteenth Amendment was never intended to apply only to former slaves. Indeed, among the core of its concerns was the protection of free speech, peaceable assembly, and the right to keep and bear arms by white, as well as black, supporters of Reconstruction. ${ }^{145}$ Both before and after the Civil War, the civil liberties of white unionists and abolitionists were severely restricted in the South, much to the dismay of Northern Republicans. ${ }^{146}$

Moreover, the principles that were advanced against slavery applied to whites in another way. Abolitionists had developed a principle known as "free labor."147 The right to one's labor was one's own, they argued, and could be alienated only by consent. Even when a contract to work for another was made, such contracts could not be

143 Slaughter-House Cases, 83 U.S. (16 Wall.) at 129 (Swayne, J., dissenting).

144 Id. at 130 (Swayne, J., dissenting).

145 See generally CurTIS, supra note 80.

146 See Michael Kent Curtis, The 1837 Killing of Elijah Lovejoy by an Anti-Abolition Mob: Free Speech, Mobs, Republican Government, and the Privileges of American Citizens, 44 UCLA L. REv. 1109, 1120 (1997) (discussing how states in the South abridged the First Amendment rights of abolitionists).

147 For the history of the American tradition of free labor, see generally ERIC Foner, Free Soil, Free labor, Free Men: The Ideology of the Republican Party Before the Civil War (1970); Robert J. Steinfeld, The Invention of Free Labor: The Employment Relation in English and American Law and Culture, 1350-1870 (1991). 
specifically or coercively enforced. ${ }^{148}$ As was explained in the 1865 case of Ford $v$. Jermon,

[i]s it not obvious that a contract for personal services thus enforced would be but a mitigated form of slavery, in which the party would have lost the right to dispose of himself as a free agent, and be, for a greater or less length of time, subject to the control of another? ${ }^{149}$

Like the Thirteenth Amendment, which prohibited involuntary servitude, the free labor principle protected whites as well as blacks. Although the facts in Slaughter-House did not concern African slavery or its vestiges, the dissent nonetheless understood the liberty to pursue an occupation to be a fundamental right closely related to "free labor." The monopoly granted by Louisiana, they argued, directly abridged the right to pursue the lawful occupation of butcher by depriving butchers of the requisite of maintaining a slaughterhouse.

Soon after its adoption, then, the Fourteenth Amendment was invoked by citizens seeking protection of their liberties from improper restrictions by states that were not (apparently) motivated by racial discrimination. While the decision in Slaughter-House effectively foreclosed using the Privileges or Immunities Clause for this purpose, the theories advanced by the four dissenters were later shifted to the Due Process Clause and, for a time, came to prevail.

Although the Privileges or Immunities Clause was largely gutted by the conventional interpretation of the Slaughter-House Cases, ${ }^{150}$ there are signs that it is not yet a dead letter. ${ }^{151}$ Moreover, after Slaughter-House, the courts began using the Due Process and Equal Protection Clauses to provide much the same constraint on state power that was originally intended to result from the Privileges or Immunities Clause, albeit with less textual justification. The "absolute" protection against laws that violate the privileges or immunities of all citizens has been shifted to the Due Process Clause, although not to the degree warranted by the original meaning of the Privileges or Im-

148 See Lea S. VanderVelde, The Gendered Origins of the Lumley Doctrine: Binding Men's Consciences and Women's Fidelity, 101 YALE L.J. 775, 795-99 (1992) (describing how the free labor concept affected early judicial stances towards specific performance of labor contracts).

149 Ford v. Jermon, 6 Phila. 6, 7 (1865). The suit concerned the specific performance of an actor. Plaintiff Ford was also the owner of the theater in which Lincoln was murdered.

150 Though this interpretation may have exaggerated the degree to which the majority opinion in the Slaughter-House Cases undercut the application of the Bill of Rights to the states. See Newsom, supra note 142, at 666 .

151 See, e.g., Saenz v. Roe, 526 U.S. 489, 501 (1999) (grounding the unenumerated right to travel in the Privileges or Immunities Clause). 
munities Clause. Likewise, the protection against laws that discriminated against a particular class of citizens was shifted to the Equal Protection Clause, the original purpose of which was to require the state judiciary and executive branch officials equally to apply and enforce necessary and proper laws.

\section{Construing What The Constitution Does Not Say: The Police Power of the States}

With the meaning of the Ninth and Fourteenth Amendments in hand, we are in a position finally to consider the proper scope of state power. Our task is to define the scope of the power left in the hands of state government that is consistent with the above conception of the liberty rights "retained by the people" as well as the "privileges or immunities" of citizens. Given that no provision of the written Constitution specifies the power of states over their citizens, any such doctrine of state power must be a constitutional construction-but one that is consistent with the equal protection of liberty rights, privileges or immunities retained by the people explicitly protected by the text.

Strictly speaking we are not seeking a doctrine of what powers are delegated to states under the Constitution. We are seeking a doctrine to identify those powers that the people of the states may, if they choose, delegate to their state governments by means of their state constitutions without violating the Constitution of the United States. Any assessment of the power held by a particular state must begin by examining its constitution. In this Article, I am considering only the proper scope or limits of the powers that may, but need not be, delegated to a particular state government by its constitution.

The most obvious power of states that follows from the original meaning of the Privileges or Immunities Clause is the power to prohibit any violations by some citizens of the liberties or rights of other citizens. In addition to the power of prohibiting wrongful conduct, the power of states may also properly include the power of regulating rightful behavior. It is no coincidence, then, that this very conception of state power came to be advocated by courts and commentators seeking to respect and protect the background rights of the people. This power was called the power of police or the "police power" of the states. It is notorious for being difficult to define and limit. ${ }^{152}$

152 See, e.g., 1 John W. Burgess, Political Science and Comparative Constitutional Law: Sovereignty and Liberty 213 (Boston, Ginn \& Co. 1890) ("I can find no satisfactory definition of this phrase, 'police power,' in the decisions of the Supreme Court itself."); Walter Wheeler Cook, What is the Police Power?, 7 Colum. L. Rev. 322,322 (1907) ("No phrase is more frequently used and at the same time less under- 


\section{A. Origins of the Doctrine of the "Police" Power}

Because the police power of states was not included in the text of the original Constitution, we are not bound by what the Founders may have thought this concept entailed. Nevertheless, examining the few instances where it was discussed reveals that it referred originally to those powers not delegated to the federal government. The phrase "internal police" was used seven times by delegates to refer to the power of state governments; once this power was referred to as "their police." 153 The issue of the police power of states arose when the Convention was still considering making a general grant of power to the national government, but wished to ensure that the "[National Legislature should] not . . . interfere with the government of the individual States in any matters of internal police . . . wherein the general welfare of the United States is not concerned." ${ }^{54}$ In The Federalist, Hamilton employed the term "domestic police" twice in essays denying that the national government was a threat to state power. ${ }^{155}$

The term "police" was rarely used in the state ratification conventions. On two occasions in New York it was used to refer to the power of states. John Williams insisted that "[t] he constitution should be so formed as not to swallow up the state governments: the general government ought to be confined to certain national objects; and the states should retain such powers as concern their own internal police."156 Hamilton contended that there might be more force in this type of objection,

[w] ere the laws of the Union to new-model the internal police of any state; were they to alter, or abrogate at a blow, the whole of its

stood than the one which forms the subject of the present discussion."); Collins Denny, Jr., The Growth and Development of the Police Power of the State, $20 \mathrm{MICH}$. L. Rev. 173,173 (1921) ("The police power of the state is one of the most difficult phases of our law to understand, and it is even more difficult to define it and to place it within any bounds.").

153 See 1 The Records of the Federal Convention of 1787, at 165 (Max Farrand ed., 3d ed. 1966) (statement of Mr. Williamson, June 8, 1787); 2 id. at 21 (Journal of the Convention, July 17, 1787); 2 id. at 25 (statement of Mr. Sherman, July 17, 1787); 2 id. at 26 (statement of Mr. Morris, July 17, 1787); 2 id. at 367 (statement of Mr. Rutledge, Aug. 22, 1787); 2 id. at 629 (statement of Mr. Sherman, Sept. 15, 1787); 2 id. at 630 (statement of Mr. Sherman, Sept. 15, 1787).

$1542 \mathrm{id}$. at 21 (quoting from a resolution proposed to the convention).

155 See The Federalist No. 17, supra note 12, at 118 (Alexander Hamilton) ("The regulation of the mere domestic police of a State appears to me to hold out slender allurements to ambition."); THE Federalist No. 34, supra note 12, at 209 (Alexander Hamilton) (referring to "expenses arising from those institutions which are relative to the mere domestic police of a state").

1562 Elliot's Debates, supra note 43, at 241. 
civil and criminal institutions; were they to penetrate the recesses of domestic life, and control, in all respects, the private conduct of individuals. ${ }^{157}$

Elsewhere, the term was used during the debate over the powers of Congress to control the national capital. In Pennsylvania, it was proposed that the Constitution be amended so that the powers of Congress "be qualified by a proviso that such right of legislation extend only to such regulations as respect the police and good order thereof."158 The term "police" was also used in the same manner several times in the Virginia convention. ${ }^{159}$

Only slight elaboration is added by St. George Tucker in his treatise on the Constitution:

The congress of the United States possesses no power to regulate, or interfere with the domestic concerns, or police of any state: it belongs not to them to establish any rules respecting the rights of property; nor will the constitution permit any prohibition of arms to the people; or of peaceable assemblies by them, for any purposes whatsoever, and in any number, whenever they may see occasion. ${ }^{160}$

In none of these uses, however, is the scope of this power made clear. What, then, did it mean?

In one sense, the term is almost completely open-ended. Samuel Johnson defined "police" as "[ $\mathrm{t}]$ he regulation and government of a city or country, so far as regards the inhabitants." 161 Apart from reinforcing the distinction between "regulate" and, "govern" that I have examined elsewhere, ${ }^{162}$ this definition adds only the idea that the police power is a power over individuals (as opposed to a power over subsidiary governmental units). It adds little to our understanding the proper scope of the power to regulate and govern individuals. The same can be said about the early Supreme Court opinions by

1572 id. at $267-68$.

$1582 i d$. at 545.

159 See e.g., 3 id. at 432 (statement of Mr. Mason, June 16, 1788); 3 id. at 434 (statement of Mr. Grayson, June 16, 1788).

160 Tucker, supra note 33, at 315-16. Notice Tucker's statement that the right to arms forbids disarming people, that this is an equivalent to the individual right of assembly, and note also his use of the term "prohibition" to denote what the right to keep and bear arms bars.

1612 Samuel Johnson, Dictionary of the English Language (London, W. Strahan 1755).

162 See Randy E. Barnett, New Evidence of the Original Meaning of the Commerce Clause, 55 Ark. L.. Rev. 847, 863-65 (2003); Randy E. Barnett, The Original Meaning of the Commerce Clause, 68 U. CHI. L. Rev. 101, 139-43 (2001). 
John Marshall distinguishing the "regulations of interstate commerce" from "police power regulations." 163

As Laurence Tribe has noted, "these labels appear to have been largely conclusory; whatever their internal coherence or their predictive value for those who used them, they reveal little of the analysis underlying the decisions in which they played a role." 164

As a doctrine, the police power is of recent vintage. As one influential commentator wrote in 1900:

The Police Power is a well recognized if not yet fully defined department of constitutional law. It is also the newest one of anything near equal importance. The 1898 edition of Bouvier's Law Dictionary says that the law on this subject is all of recent growth, and most of it is in the last half of the nineteenth century. It could not consistently say otherwise. The work as originally published in 1839 did not define the phrase "Police Power" nor even contain it. The thirteenth edition in 1867 did not have it. It was only in 1883 that this standard dictionary of law first explained the phrase. The voluminous United States Digest did not include the phrase, either in its original edition or in its revision in 1873, among its separate headings, nor among its subdivisions of constitutional law. It was not until 1879 that it began to appear among the subdivisions of constitutional law in the annual supplements of that work. ${ }^{165}$

The original meaning of the police power is notoriously hard to define, for good reason. As this evidence shows, until the Fourteenth Amendment, it was simply that power contained in state constitutions, which did not conflict with the powers delegated to the United States or prohibited by it to the states. Its scope was therefore a matter of textual interpretation and construction by state courts. Because of the Supremacy Clause, federal courts did not need to examine the scope of the police power as, whatever its scope, it was simply trumped by any express prohibition or inconsistent delegated federal power. Therefore, until passage of the Fourteenth Amendment, there simply was no reason to develop what might be called a "positive theory" of the police power that could trump even state constitutions. Such a theory immediately became necessary, however, once the Constitution was amended to give the national government the power to protect the privileges or immunities of citizens from infringements by their own state governments. And such a theory was swiftly produced.

163 See, e.g., Gibbons v. Ogden, 22 U.S. (9 Wheat.) 1, 209-1.0 (1824).

1641 Laurence H. Tribe, American Constitutional. Law 1047 (3d ed. 2000).

165 W.G. Hastings, The Development of Law as Illustrated by the Decisions Relating to the Police Power of the State, 39 Proc. Am. PHIL. Soc'y 359, 359-60 (1900). Hastings's analysis was widely cited and relied upon by other works on the subject. 


\section{B. The Lockean Theory of the Police Power}

In 1868, the same year the Fourteenth Amendment was enacted, the first edition of Thomas M. Cooley's A Treatise on the Constitutional Limitations Which Rest Upon the Legislative Power of the States of the American Union was published. ${ }^{166}$ Cooley, then a justice on the Michigan Supreme Court and the Jay Professor of Law at the University of Michigan, sought to address the question of "conflict between national and State authority" as well as the question of "whether the State exceeds its just powers in dealing with the property and restraining the actions of individuals." 167 The answers to these questions turned on the content of the police power, which he defined in light of previous judicial opinions as follows:

The police of a State, in a comprehensive sense, embraces its system of internal regulation, by which it is sought not only to preserve the public order and to prevent offences against the State, but also to establish for the intercourse of citizen with citizen those rules of good manners and good neighborhood which are calculated to prevent a conflict of rights, and to insure to each the uninterrupted enjoyment of his own, so far as is reasonably consistent with a like enjoyment of rights by others. ${ }^{168}$

The last part of this definition can be conceptualized as the power of a state to protect the rights of each of its citizens from being violated by any other person in society and to permit the exercise of one's rights in such a manner as to prevent such exercise from intruding upon the like rights of others. Whereas the protection afforded common law rights by adjudication occurs after they have been violated, police power regulations seek to facilitate or "make regular" the exercise of these rights and prevent their infringement before the fact. ${ }^{169}$ Whereas damage actions compensate for past violations of rights, the police power permits laws necessary to prevent rights violations from occurring.

There is no enumeration or list of specific state powers for much the same reason the Founders thought rights could not be comprehensively listed. Just as all the ways that liberty may be exercised right-

166 Thomas M. Cooley, A Treatise on the Constitutional Limitations Which Rest Upon the Legislative Power of the States of the American Union (Boston, Little, Brown \& Co. 1866).

167 Id. at 572.

168 Id.

169 I refer to "police power regulation" because, in Lockean theory, adjudication is also an exercise of police power. See infra notes 172-88 and accompanying text. 
fully cannot be enumerated in advance, neither can all the specific ways that people may transgress upon the rights of others:

It would be quite impossible to enumerate all the instances in which this power is or may be exercised, because the various cases in which the exercise by one individual of his rights may conflict with a similar exercise by others, or may be detrimental to the public order or safety, are infinite in number and in variety. ${ }^{170}$

Like the modern doctrine that views content-neutral "time, place, and manner" regulations of speech to be consistent with the First Amendment, the police power provides the states with the authority "to make extensive and varied regulations as to the time, mode, and circumstances in and under which parties shall assert, enjoy, or exercise their rights, without coming in conflict with any of those constitutional principles which are established for the protection of private rights or private property." 171

Cooley's conception of the police power descended from the same Lockean natural rights theory on which the Ninth Amendment and the Privileges or Immunities Clause were based. In the prepolitical "state of nature," people are in possession of all their natural rights, including the right to execute or enforce their rights against other persons. "[I]n the state of Nature," wrote Locke, "every one has the Executive Power of the Law of Nature." 172 However, in such a state, it can be objected that "it is unreasonable for Men to be Judges in their own Cases, that Self-love will make Men partial to themselves and their Friends. And on the other side, that Ill Nature, Passion and Revenge will carry them too far in punishing others." 173 For this reason, "nothing but Confusion and Disorder will follow," and government is needed "to restrain the partiality and violence of Men."174

Locke readily conceded

that Civil Government is the proper Remedy for the Inconveniences of the State of Nature, which must certainly be Great, where Men may be Judges in their own Case, since 'tis easily to be imagined, that he who was so unjust as to do his Brother an Injury, will scarce be so just as to condemn himself for it. ${ }^{175}$

For this reason,

170 CoOley, supra note 166 , at 594 .

$171 \quad I d$. at 597.

172 LOCKE, supra note 61, at 275.

173 Id.

$174 I d$. at $275-76$.

175 Id. at 276. 
the Community comes to be Umpire, by settled standing Rules, indifferent, and the same to all Parties; and by Men having Authority from the Community, for the execution of those Rules, decides all the differences that may happen between any Members of that Society, concerning any matter of right; and punishes those Offences which any Member hath committed against the Society, with such Penalties as the Law has established. ${ }^{176}$

For Locke, an impartial judiciary applying a common law defines "civil society":

Those who are united into one Body, and have a common establish'd Law and Judicature to appeal to, with Authority to decide Controversies between them, and punish Offenders, are in Civil Society one with another: but those who have no such common Appeal, I mean on Earth, are still in the state of Nature, each being, where there is no other, Judge for himself, and Executioner; which is, as I have before shew'd it, the perfect state of Nature. ${ }^{177}$

Thus, according to Lockean political theory, the first duty of government is to provide standing general rules for the equal protection of the rights retained by each person, and these rights, in turn, provide the baseline against which to assess the propriety of government actions and the justice of positive rules of law. But Locke also cautioned those who saw government as the solution to the inconveniences of the state of nature that these inconveniences did not justify a Leviathan with unlimited power of the sort advocated by Hobbes:

Absolute Monarchs are but Men, and if Government is to be the Remedy of those Evils, which necessarily follow from Mens being Judges in their own Cases, and the State of Nature is therefore not to be endured, I desire to know what kind of Government that is, and how much better it is than the State of Nature, where one Man, commanding a multitude, has the Liberty to be Judge in his own Case, and may do to all his Subjects whatever he pleases, without the least liberty to any one to question or controle those who Execute his Pleasure? And in whatsoever he doth, whether led by Reason, Mistake or Passion, must be submitted to ${ }^{178}$

From this, Locke concluded that the state of nature with no government is preferable to an "absolute" or unlimited government, because at least in the state of nature, "Men are not bound to submit to the unjust will of another: And if he that judges, judges amiss in his

$176 I d$. at 324.

177 Id.

$178 I d$. at 276. 
own, or any other Case, he is answerable for it to the rest of Mankind."179

The propriety of the laws made by the legislature is dictated by the rationale for yielding the lawmaking power to the government. "Men, when they enter into Society, give up the Equality, Liberty, and Executive Power they had in the State of Nature, into the hands of the Society, to be so far disposed of by the Legislative, as the good of the Society shall require." 180 This "good of society," however, is no openended grant of power simply to do good; as was discussed above, ${ }^{181}$ it is defined and limited by the rights retained by the people when they surrender their powers of enforcement, and this is what makes it a genuine common good or good for everyone, not merely a segment or faction of society.

[I]t being only with an intention in every one the better to preserve himself his Liberty and Property; (For no rational Creature can be supposed to change his condition with an intention to be worse), the power of the Society, or Legislative constituted by them, can never be suppos'd to extend farther than the common good . . . . ${ }^{182}$

And to secure this "common good," the legislature "is obliged to secure every ones Property by providing against those three defects . . . that made the State of Nature so unsafe and uneasie."183

These three defects are (1) the want of "an establish'd, settled, known Law, received and allowed by common consent to be the Standard of Right and Wrong, and the common measure to decide all Controversies between them";184 (2) the want of "a known and indifferent Judge, with Authority to determine all differences according to the established Law"; 185 and (3) the want of the "Power to back and support the Sentence when right, and to give it due Execution."186 Therefore,

whoever has the Legislative or Supream Power of any Commonwealth, is bound to govern by establish'd standing Laws, promulgated and known to the People, and not by Extemporary Decrees; by indifferent and upright Judges, who are to decide Controversies by

179 Id.

180 Id. at 371.

181 See supra notes 49-54 and accompanying text.

182 LOCKE, supra note 61 , at 371.

$183 I d$.

$184 I d$. at 369.

185 Id.

186 Id. 
those Laws; And to imploy the force of the Community at home, only in the Execution of such Laws . . . ${ }^{187}$

According to Lockean political theory, then, because people form government to secure their rights of liberty and property more effectively than they can secure them on their own, the executive or police power must be limited to the advancement of the common good, which is accomplished by protecting those same retained rights. In this way, Lockean theory provides both a powerful rationale for and an important limit upon the powers of government that is reflected in the police power doctrine. The police power is the legitimate authority of states to regulate rightful and prohibit wrongful acts.

The relationship between the exercise of inalienable natural liberty rights and regulation was nicely described by Charles Bufford in 1916, and is worth quoting at length:

[I]f, in attempted exercise of inalienable rights, an individual should do with his own or conduct himself as he willed, without the internal restraint of conscience or the external restraint of law, others less able than himself to assert and defend their personal and property rights would, by reason of his unregulated assertion of his own personal and property rights, inevitably suffer an infringement of their equally inalienable rights. The common experience of mankind is that the restraints of conscience can not be relied upon in every case to restrain individuals from infringing the rights of others. Thus, that men may live together in society and enjoy some equality [in] their inalienable rights, it becomes necessary that each be subjected in the enjoyment of his own rights to at least some measure of regulation by legislation.

In other words, the guaranty of individual freedom and individual property, of the right of the individual to do with his own and to conduct himself as he wills, can not be applied abstractly as though there were but one individual and he a law unto himself; but must be applied concretely in the light of the relationship of each individual to others, and of the principle necessary to the friendly intercourse of men with men as equals expressed in the maxim, sic utere tuo ut alienum non laedas, "so use your own as not to injure another's." ...

It thus appears that the inalienable rights of every one are subject to such regulation by legislation as tends to prevent him in the exercise of his own inalienable rights from unreasonably infringing

187 Id. at 371 . 
upon those of others, and to secure to him the same uninterrupted enjoyment of his own inalienable rights as others enjoy. ${ }^{188}$

Unsurprisingly, the Lockean theory of the police power adopted by Cooley and others to identify when states violate the injunctions of the Fourteenth Amendment is generally consistent with the conception of natural rights to which the framers of the Constitution and Fourteenth Amendment adhered. (And it would need to be so to avoid violating this amendment.) Natural rights define the boundary or space within which people are at liberty to do as they please, provided their actions do not interfere with the rightful actions of others operating within their own boundaries or spaces. Just as it is proper to prohibit wrongful or rights-violating conduct, proper police power regulations specify the manner in which persons may exercise their liberties so as to prevent them from accidentally interfering with the rights of others.

Cooley was not the only theorist to put flesh on the bones of this Lockean natural rights theory of police power. After Cooley, the leading nineteenth century theorist of the police power was Professor Christopher Tiedeman. In his 1886 A Treatise on the Limitations of Police Power in the United States Considered from both a Civil and Criminal Standpoint, ${ }^{189}$ he repeatedly relied on the power to prevent rights violations to identify reasonable and therefore constitutional exercises of the police power. To explain the police power and its limits he began with the concept of natural rights:

The private rights of the individual, apart from a few statutory rights, which when compared with the whole body of private rights are insignificant in number, do not rest upon the mandate of municipal law as a source. They belong to man in a state of nature; they are natural rights, rights recognized and existing in the law of reason. ${ }^{190}$

Like Locke, Tiedeman defined the legitimate purpose of government as the protection of these rights. "The object of government is to impose that degree of restraint upon human actions, which is necessary to the uniform and reasonable conservation and enjoyment of private rights. Government and municipal law protect and develop, rather than create, private rights." ${ }^{191}$ Government protects and develops these rights by preventing people from violating the rights of

188 Charles Bufford, The Sciope and Meaning of Police Power, 4 CAL. L. REv. 269, 269, 272 (1916).

189 Tiedeman, supra note 1.

$190 I d$. at 1.

191 Id. 
others. "The conservation of private rights is attained by the imposition of a wholesome restraint upon their exercise, such a restraint as will prevent the infliction of injury upon others in the enjoyment of them. . . The power of the government to impose this restraint is called POLICE POWER." 192

While the Lockean theory of the police power, as developed by Cooley, Tiedeman, and others, was generally consistent with the background rights retained by the people, this power was sometimes construed more broadly than was proper. In particular, the police power was typically construed to empower states to protect not only the "health and safety" of the general public, but its "morals" as well. For example, in the 1887 case of Mugler $v$. Kansas, Justice Harlan rejected a Fourteenth Amendment challenge to the prohibition of manufacturing and selling alcohol on the ground that "[i]t cannot be supposed that the States intended, by adopting that Amendment, to impose restraints upon the exercise of their powers for the protection of the safety, health, or morals of the community." 193 By this rationale, courts upheld the power of states to prohibit gambling, the consumption of alcohol, prostitution, doing business on the Sabbath, and other types of activities that did not violate the rights of others.

Some of these expansions were recognized by leading police power theorists as improper even at the time. Christopher Tiedeman, for example, contended that legislation prohibiting gambling "would be open to serious constitutional objections. Gambling or betting of any kind is a vice and not a trespass, and inasmuch as the parties are willing victims of the evil effects, there is nothing which calls for public regulation." 194 According to this view, "[n]o law can make vice a crime, unless it becomes by its consequence a trespass upon the rights of the public." 195 For Tiedeman, the protection of rights is the measure of proper police power regulations.

\section{Id. at 1-2.}

193 Mugler v. Kansas, 123 U.S. 623, 664 (1887) (emphasis added). In Mugler, Justice Harlan explained why judicial review was essential to cabin the police power:

If . . a statute purporting to have been enacted to protect the public health, the public morals, or the public safety, has no real or substantial relation to those objects, or is a palpable invasion of rights secured by the fundamental law, it is the duty of the courts to so adjudge, and thereby give effect to the Constitution.

Id. at 661 .

194 Tiedeman, supra note 1 , at 260.

$195 I d$. at 291. Tiedeman also thought that "when they pursue gambling as a business, and set up a gambling house, like all others who make a trade of vice, they may be prohibited and subjected to severe penalties." Id. at 260 (emphasis added). An explicit rationale for this distinction is not provided, but most likely it stems from 
Tiedeman discusses at some length why temperance laws were not only bad policy, but also beyond the state's police power. " $[\mathrm{N}] \mathrm{o}$ trade can be subjected to police regulation of any kind," wrote Tiedeman, "unless its prosecution involves some harm or injury to the public or to third persons, and in any case the regulation cannot extend beyond the evil which is to be restrained."196 Moreover, "no trade can be prohibited altogether, unless the evil is inherent in the character of the trade, so that the trade, however conducted, and whatever may be the character of the person engaged in it, must necessarily produce injury upon the public or upon individual third persons." 197

After a lengthy examination of the effects of the use and sale of alcohol, Tiedeman concluded that prohibition was not constitutionally justified under the principles of the police power. "[T]he liquor trade can not . . . be prohibited entirely, unless its prosecution is essentially and necessarily injurious to the public. Even the prohibition of saloons, that is, where intoxicating liquor is sold and served, to be drunk on the premises, cannot be justified on these grounds." $198 \mathrm{Al}-$ though the courts of his day rejected this view, Tiedeman contended that it was "the duty of a constitutional jurist to press his views of constitutional law upon the attention of the legal world, even though they place him in opposition to the current of authority." 199

Although Tiedeman could not justify the prohibition of the liquor trade on private property, he found it different when a state acts as an owner of property, such as its own offices and buildings, or as the guardian of public spaces, such as streets and parks. In the latter instance, it may properly constrain conduct, such as public fornication or intoxication, that adversely affects other members of the general public from enjoying its use. Immoral actions like these, though per-

Tiedeman's conception of "public harm." While private vice, of itself, works no necessary harm on the general public, Tiedeman appears to have thought that the business of supplying such vices does. He seems not to have understood that the legal suppression of such business creates enormous harm to the general public.

$196 I d$. at 301.

197 Id. at 301-02 (emphasis added).

$198 I d$. at 307.

$199 I d$. at 311 . Thus I believe it is wrong to claim that "Cooley and Tiedeman, with the characteristic dogmatism of treatise writers, asserted that their views were "the law.' Paul Brest et al., Processes of Constitutional Decisionmaking: Cases and Materials 350 (2000). While Cooley hewed closely to precedent, Tiedeman was a bit more normative, stating clearly where his views differed with the cases. As a result, Tiedeman's thesis was somewhat more radical than Cooley's. Of course, both attempted to synthesize "the law" and in so doing emphasized some authorities while de-emphasizing others. 
mitted behind closed doors, can wrongfully interfere with the use and enjoyment of the public sphere by reasonable members of the community and their children. Provided such restrictions on freedom were shown to be necessary to this end and not violative of some other constitutional prohibition, ${ }^{200}$ these sorts of protection of "public morals" would be within the Lockean construction of the police power of the states identified here.

On the other hand, were the state allowed the power to prohibit any purely private activity on the sole ground that a majority of the legislature deems it to be immoral, there would be no limit on state power since no court could review the rationality of such a judgment. As between the legislature and a citizen, the legislature would improperly be the judge in its own case. Imposing so unlimited a power on nonconsenting citizens would be an illegitimate construction of state power in no way mandated by the original meaning of the Constitution. "[T] his regulatory power," wrote Bufford, "does not authorize interference with individual freedom or individual property to protect individuals from doing injury to themselves, unless consequences harmful to the public, tend to result."201

\section{Distinguishing Proper From Improper Exercises of State Power}

How can a proper regulation of rightful activity be distinguished from an improper abridgment of the private rights of the people? As with federal laws, the key is whether state laws are a pretext for purposes other than the prevention of future or rectification of past rights violations. "[A] regulation in the exercise of the police power, to be valid must not be unreasonably or unnecessarily burdensome, and must have some appreciable tendency towards accomplishing a result within the scope of police power."202 One sign that a law is pretextual is when it benefits a particular group rather than the general public. This type of inquiry was emphasized and developed by the courts during the Reconstruction and Progressive Eras.

Building on the Lockean idea of the "common good," courts examined whether a particular law benefited every person in the community as a whole or whether it instead was implemented for the benefit of a majority or minority faction (what today would be called a "special interest" group). As was stated by Justice Bradley in his Slaugh-

200 Laws that improperly discriminate against some class of citizens, for example, would still be barred by the original meaning of the Privileges or Immunities Clause, or by the modern interpretation of the Equal Protection Clause.

201 Bufford, supra note 188, at 276.

202 Id. at 277. 
ter-House dissent: “[F] undamental rights . . . can only be interfered with . . . by lawful regulations necessary or proper for the mutual good of all."203 The paradigm of a law that exceeded the police power to regulate rightful or prohibit wrongful conduct was a law that, in the words of Justice Samuel Chase in Calder $v$. Bull, "takes property from $A$. and gives it to $\mathrm{B}^{204}$ or from group $A$ to group $B$. As explained by Bufford:

Thus any law which undertakes to abolish personal or property rights, the exercise of which does not involve an infringement of the rights of others, or to limit the exercise of rights beyond what is necessary to provide for the public welfare and general security, is not within the police power, but constitutes an unwarrantable invasion of individual rights. ${ }^{205}$

"An exercise of legislative powers would be considered valid," explains Howard Gillman, "only if it could reasonably be justified as contributing to the general welfare. The adjudicative task was to give meaning to this standard."206 Gillman has shown how great effort was expended by federal and state courts throughout the Progressive Era to develop sophisticated doctrines by which special interest legislation could be distinguished from general interest legislation that served a common good.

Specifically, it came to be determined, first, that laws that singled out specific groups or classes for special treatment would withstand constitutional scrutiny only if they could be justified as really related to the welfare of the community as a whole . . . and were not seen as corrupt attempts to use the powers of government to advance purely "private" interests . . . ; and, second, that acts that interfered with an individual's property or market liberty would be considered legitimate so long as they were not designed to advance the interests of just certain groups or classes. ${ }^{207}$

This project actually originated in state courts decades before the enactment of the Fourteenth Amendment, when interest groups began organizing to obtain special benefits from early state legislatures. ${ }^{208}$ Policing the vast array of legislative initiatives consistently from statute to statute was not always easy in a system in which a $\mathrm{Su}$ preme Court of nine Justices oversaw numerous lower federal and

203 Slaughter-House Cases, 83 U.S. (16 Wall.) 36, 116 (1872) (Bradley, J., dissenting).

2043 U.S. (3 Dall.) 386, 388 (1798) (emphasis omitted).

205 Bufford, supra note 188, at 275.

206 Gillman, supra note 7, at 49.

207 Id. at $49-50$.

208 See id. at $45-60$. 
state courts comprised of innumerable judges. Gillman demonstrates that, despite the difficulties of such an inquiry, these efforts were remarkably coherent and also consistent with the political principles of the founding generation.

Gillman's important work has two major themes. The first is that "Lochner Era police powers jurisprudence" was both coherent and continuous with the underlying principles of the Founding. This makes the New Deal rejection of this constitutional jurisprudence a revolution, not a restoration. After this revolution, unless a right deemed by the Court to be fundamental is violated, "Congress need not justify intervention itself, . . . need not justify intervening to favor some participants in the economy over others, and . . need not justify its choice of favorites."209 And neither must the states.

Gillman's second theme is that the animating principle of the "Lochner Era" was an aversion to class legislation, not an adherence to "laissez-faire." "But 'public purpose' as a limit on the powers of government did not mean 'laissez-faire'; it meant, by and large, class-neutral legislation-legislation that did not impose special burdens or benefits on certain market competitors."210 Although Gillman's evidence shows that resistance to class based legislation was undoubtedly a touchstone by which reasonable regulation was distinguished from arbitrary interference with liberty, I have two small quarrels with this last claim.

First, because Gillman misunderstands "laissez-faire," he is rejecting a straw man. Laissez-faire was never a claim that liberty could not be regulated. The writings of Cooley and Tiedeman testify to this. Therefore, finding that "reasonable" regulations on liberty were upheld is no evidence that courts were rejecting laissez-faire as a political end. Courts that are completely committed to laissez-faire would still uphold reasonable regulations of liberty.

Second, Gillman also underestimates the degree to which the resistance to class based legislation was seen as a means to the protection of natural rights, rather than an end in itself. That is, the identification of class based legislation could well have been thought to be a workable standard or doctrine by which infringements on natural rights could be detected and corrected. Although Gillman never really disputes this last point, his continued refrain about the rejection of laissez-faire in favor of an aversion to class based legislation sets up an opposition that goes beyond his evidence.

209 Martin Shapiro, The Supreme Court's "Return" to Economic Regulation, 1 STUD. AM. Pol. Dev. 91, 134 (1986).

210 Gillman, supra note 7, at 55. 


\section{Competing Constructions of the Police Power}

Although the Lockean conception of the police power was advocated from the very inception of the Fourteenth Amendment by commentators and jurists seeking to protect the natural liberty rights to which it referred, other conceptions of the police power existed as well. In particular, other jurists and commentators claimed a broader power of states to legislate "in the public interest." To be sure, this conception need not necessarily be any broader if one conceives of the respect for individual liberty rights to be essential to the achievement of a genuinely common good. ${ }^{211}$ Some, however, may see the protection of individual liberty rights to be more a hindrance than an aid to pursuing the public good. For such persons, so limited a construction of the police power is objectionable.

Ernst Freund is the scholar most associated with the origins of this broader conception of the police power. Writing in 1904, Freund rejected the Lockean conception of a police power defined and limited by the private "common law rights" of individuals.

But no community confines its care of the public welfare to the enforcement of the principles of the common law. The state places its corporate and proprietary resources at the disposal of the public by the establishment of improvements and services of different kinds; and it exercises its compulsory powers for the prevention and anticipation of wrong by narrowing common law rights through conventional restraints and positive regulations which are not confined to the prohibition of wrongful acts. It is this latter kind of state control which constitutes the essence of the police power. The maxim of this power is that every individual must submit to such restraints in the exercise of his liberty or of his rights of property as may be required to remove or reduce the danger of the abuse of these rights on the part of those who are unskillful [sic], careless or unscrupulous. ${ }^{212}$

Glenn Reynolds and David Kopel summarize the contrast between this position and that of Tiedeman as follows:

[T] he traditional view, espoused by Tiedman [sic], was that state power could legitimately be employed to protect individuals from direct harm; the newer view, represented by Freund, was that the state could regulate even to prevent harms that might not occur, or

211 This is the thesis of BARNETT, supra note 73.

212 Ernst Freund, The Police Power: Public Policy and Constitutional Rights 6 (1904) (emphasis omitted). 
that might not have been considered harms at all by the common law. ${ }^{213}$

Reynolds and Kopel note, however, that even Freund, "the expositor of the broad police power theory that dominated legal thought in the twentieth century, emphasized that judicial review was still essential." 214 As Freund put the matter:

Effective judicial limitations on the police power would be impossible, if the legislature were the sole judge of the necessity of the measures it enacted. ... [T] he maintenance of private rights under the requirements of the public welfare is a question of proportionateness of measures entirely. Liberty and property yield to the police power, but not to the point of destruction ....

The question of reasonableness usually resolves itself into this: Is regulation carried to the point where it becomes a prohibition, destruction, or confiscation? ${ }^{215}$

Kopel and Reynolds present much evidence that Freund's view was far from the unlimited claim of police power typically posed in opposition to the views of Cooley and Tiedeman. For example, they note Freund's endorsement of the propriety of regulating the disposal of dead bodies as a health and safety measure. Still, writes Freund, "[p]robably the courts would control legislative discretion were it exercised in an unreasonable manner. Thus a legislative prohibition of cremation on the ground that it is contrary to good morals, would not be likely to be acquiesced in by the courts ...."216 Freund acknowledged that the legislature could not be the sole judge of its own powers. "Yet if the passage of a statute were conclusive evidence of the existence of the danger and of the necessity of the remedy, the power of the legislature in the most important field of the police power would be practically unrestricted." ${ }^{17}$ Thus even into the twentieth century, the police power had not been construed to be an unlimited power, constrained only by the express prohibitions of the Constitution.

Moreover, the expanded view of the police power in the early twentieth century was sometimes conceded, by some who supported this expansion, to be in conflict with the original meaning of the Fourteenth Amendment. For example, we find Collins Denny, Jr., of Princeton, writing in the Michigan Law Review in praise of Justice Miller's opinion in Slaughter-House.

213 Glenn H. Reynolds \& David B. Kopel, The Evolving Police Power: Some Observations for a New Century, 27 Hastings Const. L.Q. 511, 512 (2000).

214 Id. at 517.

215 FreUnd, supra note 212, at 60-61 (emphasis added).

$216 I d$. at 118 (emphasis added).

217 Id. at 134. 
The judges were sympathetic with the results of the war in so far as they established the principles of territorial sovereignty, but were not ready to see the states become powerless and the whole theory of our Constitution destroyed. Fortunate indeed were we in having such a man as Justice Miller, who in time of great national disturbance was able to foresee the inherent danger of this new amendment, and who had the courage to place himself in the path of radicalism and check it.

... This decision rendered valueless the "privileges and [sic] immunities' clause in extending the national power at the expense of that of the states. ${ }^{218}$

Denny explicitly praises Miller for deviating from the original meaning of the text: "The dissenting judges undoubtedly interpreted this amendment as the framers of it had intended."219 Lest one speculate about the reason for disregarding and "render[ing] valueless" a portion of the Constitution's text as too "radical," Denny makes it explicit in a truly stunning passage: "It has been very fortunate for [the South] that the Supreme Court has given the police power such a wide range, and due to this power the South has so far been able to ward off the danger arising from her large negro population."220

Although an unlimited plenary police power is favored because it can be used for good, it can also be used for ill. Hastings saw a similar origin of the broader claim of police power although, unlike Denny, he strongly disapproved. After the Civil War, he observed, the police power was "needed . . . to enable the states to maintain their autonomy against the reconstruction legislation of Congress and the new amendments."221

The original meaning of the Fourteenth Amendment stands as a barrier by which those against whom the police power is used can seek to defend themselves in Congress and in the courts. So too does the original conception of the police power that evolved alongside the amendment. As Hastings wrote, the police power "appears clearly enough from our decisions, a branch of constitutional law peculiar to countries having legislatures with limited power. It is an outgrowth of the American conception of protecting the individual from the state.

\footnotetext{
218 Denny, supra note 152, at 190-92.

219 Id. at 191 n.46.

$220 I d$. at 201.
}

221 Hastings, supra note 165, at 550 (emphasis added). 
It originated in connection with the discussion of the limitation on the legislative powers of the states under our federal system."222

\section{Conclusion}

We can sum up this analysis of the police power of states as follows: The Fourteenth Amendment does not bar states from prohibiting wrongful exercises of freedom. There is no privilege to violate the rights of others, nor any immunity from liability should one do so. In nearly all instances, the Constitution leaves the general power to prohibit wrongful conduct where it was before its ratification: in the hands of states. It does, however, give Congress the power to prohibit and set the punishment for certain identifiable offenses, such as treason and piracy. The powers that came to be called the "police power" of the state are far from being inconsistent with the rights retained by the people. To the contrary, properly construed, the protection of individual rights is at the core of a state's police power.

A state may also justify its laws by showing that it is merely regulating liberty in a way that protects the rights of others. The Fourteenth Amendment bars states from "abridging" or violating the privileges or immunities of citizenship. It does not bar them from subjecting these privileges to publicly accessible "standing rules" of law, provided that such rules are also shown to be necessary to protect the rights that everyone possesses. In this manner, although the Fourteenth Amendment bars the abridgment of liberty and permits liberty-restricting laws to be challenged in federal court, it does not prevent legislatures from reasonably regulating the exercise of private rights.

Finally, in addition to prohibiting wrongful and regulating rightful private behavior that may injure the rights of others, the state may also manage government controlled public space so as to enable members of the public to enjoy its use, and may restrict the use of its own property provided these regulations and restrictions do not improperly violate other constitutional prohibitions on state power.

All these principles are illustrated nicely by the decision in Lawrence $v$. Texas, ${ }^{223}$ in which the Supreme Court struck down a state statute criminalizing sexual conduct-or "sodomy"-between persons of the same sex. Although Justice Kennedy, writing for the majority, did not explicitly employ the view of the police power identified here, his opinion could be interpreted as implicitly doing so. He does not find

222 Id. at 360.

223123 S. Ct. 2472 (2003). I discuss the Lawrence case at greater length in Randy E. Barnett, Justice Kennedy's Libertarian Revolution: Lawrence v. Texas, 2002-2003 Cato Sup. Ct. Rev. 21. 
the prohibited conduct to be the exercise of a "fundamental right" of privacy calling for strict scrutiny of the statute. Instead, his opinion rests entirely on the liberty protected by the Fourteenth Amendment: "We conclude the case should be resolved by determining whether the petitioners were free as adults to engage in the private conduct in the exercise of their liberty under the Due Process Clause of the Fourteenth Amendment to the Constitution."224 The bulk of the opinion is taken up defending the characterization of conduct in question as liberty rather than as license:

Liberty protects the person from unwarranted government intrusions into a dwelling or other private places. In our tradition the State is not omnipresent in the home. And there are other spheres of our lives and existence, outside the home, where the State should not be a dominant presence. Freedom extends beyond spatial bounds. Liberty presumes an autonomy of self that includes freedom of thought, belief, expression, and certain intimate conduct. The instant case involves liberty of the person both in its spatial and more transcendent dimensions. ${ }^{225}$

Having defined the conduct as liberty, Justice Kennedy then requires the state to have a legitimate reason for interfering with its exercise. The only reason offered by the government in its defense is that the legislature deemed the conduct to be immoral, a justification Justice Kennedy found to be inadequate: "the fact that the governing majority in a State has traditionally viewed a particular practice as immoral is not a sufficient reason for upholding a law prohibiting the practice; neither history nor tradition could save a law prohibiting miscegenation from constitutional attack."226

The decision in Lawrence implicitly rejects the view of the police power as unlimited and plenary and is entirely compatible with the analysis presented here. The defendants in this case were exercising their unenumerated right, or liberty, to use their bodies as they chose. Because their activity, performed entirely behind closed doors, did not wrongfully interfere with the equal rights of others to their persons or property, it is properly characterized as liberty, as opposed to licence. By prohibiting the rightful exercise of liberty, the statute exceeds the proper scope of the police power.

Although the state could possibly regulate, as opposed to prohibit, a rightful exercise of liberty, such a regulation would have to be

224 Lawrence, 123 S. Ct. at 2476 (emphasis added).

225 Id. at 2475 (emphases added).

226 Id. at 2483 (quoting Bowers v. Hardwick, 478 U.S. 186, 216 (1986) (Stevens, J., dissenting)). 
shown to be necessary to the protection of the rights of others. For example, the state might say that if you are to engage in such conduct, it must not be done in a public place where members of the general public might view it. A bare assertion that the conduct in question is immoral is inadequate, however, since such an assertion could always be made, potentially justifying any regulation or prohibition. Such a construction exceeds the proper scope of the police power because it violates the privileges or immunities protected by the Fourteenth Amendment-the liberty that, due to the Slaughter-House Cases, is now protected instead by the Due Process Clause.

By the theory of the police power presented here, Lawrence $v$. Texas is, therefore, an easy case. Any effort to identify the proper scope of the police power of states requires either Congress or the courts to draw a line between permissible and impermissible justifications for prohibition and regulation of individual conduct. Though any effort to draw lines will sometimes be vexatious, Lawrence illustrates how it can also be quite straightforward. Whether hard or easy, however, the original meaning of the Privileges or Immunities Clause rules out the unlimited or plenary conception of state power and mandates that states justify any restrictions on the actions of their citizens as within the proper scope of the police power. 
